\title{
ANALISIS KOMPETENSI, SARANA PRASARANA DAN PERENCANAAN PROGRAM PELATIHAN TERHADAP KUALITAS TENAGA KERJA PADA DINAS TENAGA KERJA DAN TRANSMIGRASI KABUPATEN BALANGAN KALIMANTAN SELATAN
}

\author{
Fitri Efendi \\ Sekolah Tinggi Ilmu Ekonomi Pancasetia \\ Jl. Ahmad Yani Km. 5.5 Banjarmasin \\ fendy628@gmail.com
}

\begin{abstract}
Abstrak : Fitri Efendi, Npm. 1811.32202.4732, Analisis Kompetensi, Sarana Prasarana Dan Perencanaan Program Pelatihan Terhadap Kualitas Tenaga Kerja Pada Dinas Tenaga Kerja Dan Transmigrasi Kabupaten Balangan Kalimantan Selatan, Dibawah Bimbingan Rosadiro Cahyono Dan Yudi Rahman, 2020. Tujuan penelitian yang ingin dicapai dalam penelitian ini, adalah Untuk mengetahui dan menganalisis pengaruh kompetensi terhadap kualitas tenaga kerja, Untuk mengetahui dan menganalisis pengaruh sarana prasarana terhadap kualitas tenaga kerja, Untuk mengetahui dan menganalisis pengaruh perencanaan program pelatihan terhadap kualitas tenaga kerja dan untuk mengetahui dan menganalisis pengaruh kompetensi, sarana prasarana dan perencanaan program pelatihan secara simultan terhadap kualitas tenaga kerja pada Dinas Tenaga Kerja Dan Transmigrasi Kabupaten Balangan Kalimantan Selatan. Populasi dari penelitian ini adalah tenaga kerja yang ikut pelatihan di Dinas Tenaga Kerja dan Transmigrasi Kabupaten Balangan Kalimantan Selatan yang berjumlah 224 orang sedangkan sampel dalam penelitian ini sebanyak 56 orang responden. Teknik pengolahan data yang akan dilakukan menggunakan metode kuantitatif dengan analisis regresi berganda dengan perangkat lunak spss. Hasil penelitian hiipotesis pertama menyebutkan secara parsial antara variabel kompetensi berpengaruh signifikan terhadap kualitas tenaga kerja, hipotesis kedua menyebutkan secara parsial antara variabel sarana prasarana berpengaruh signifikan terhadap kualitas tenaga kerja, hipotesis ketiga yang menyebutkan secara parsial antara variabel perencanaan program pelatihan berpengaruh signifikan terhadap kualitas tenaga kerja dan pengujian hipotesis keempat menunjukkan bahwa variabel kompentensi, sarana prasarana dan perencanaan program pelatihan secara simultan berpengaruh signifikan terhadap kualitas tenaga kerja pada Dinas Tenaga Kerja Dan Transmigrasi Kabupaten Balangan Kalimantan Selatan.
\end{abstract}

Kata Kunci : Kompetensi, Sarana Prasarana, Perencanaan Program Pelatihan dan Kualitas Tenaga Kerja 


\section{PENDAHULUAN}

\subsection{Latar Belakang Masalah}

Pegawai Negeri Sipil yang berprestasi untuk meningkatkan kemampuannya secara profesional dan berkompetensi secara sehat, sehingga setiap pegawai tentunya akan lebih bergairah dan bersemangat dalam bekerja. Dengan adanya berbagai masalah pegawai maka masalah tersebut perlu ditangani secara khusus, untuk itu perlu adanya bagian yang mengurus segala hal administrasi kepegawaian, pembinaan pegawai, dan peningkatan kinerja pegawai. Seiring dengan perubahan paradigma pemerintah yang mengarah pada pemerintahan demokratis yang berazas pada good governance, diperlukan pula pembaharuan pada tataran aparatur pemerintah yang profesional. Pengaruh terhadap peningkatkan kemajuan elemen bangsa. Untuk mewujudkan semua itu perlu ditingkatkan kesadaran dan kemampuan masyarakat dalam pengembangan sumbersumber daya alam maupun sumber daya manusia, melalui unsur-unsur yang ada didalam masyarakat itu sendiri. Oleh sebab itulah eksistensi penciptaan kualitas sumber daya manusia harus lebih dikembangkan lagi. Pengelolaan sumber daya manusia bagi keperluan sebuah organisasi merupakan salah satu dari fungsi operasional manajemen sumber daya manusia. Untuk menentukan serta menghasilkan sumber daya manusia yang produktif, terlebih dahulu diperlukan perencanaan yang matang terhadap penentuan sumber daya manusia diinginkan sesuai dengan yang dibutuhkan. Menghadapi era globalisasi suatu organisasi usaha akan sangat tergantung pada kualitas sumber daya manusia yang dimilikinya, dalam rangka meningkatkan efektifitas dan efisiensi kerja organisasi.

Guna mencapai hal tersebut banyak faktor yang mempengaruhinya diantaranya adalah kompetensi pegawai. Berbicara kemampuan atau kompetensi aparatur negara merupakan hal yang sangat penting, karena dengan adanya kompetensi yang baik, maka seorang pegawai akan mempunyai keahlian, pengetahuan, dan kemampuan yang dimiliki tinggi. Menurut Wibowo, (2010:266) kompetensi adalah kemampuan seseorang untuk menghasilkan pada tingkat kepuasan ditempat kerja, termasuk diantaranya kemampuan seseorang untuk mentransfer dan mengaplikasikan keterampilan dan pengatahuan tersebut dalam situasi yang baru dan meningkatkan manfaat yang disepakati. Selain itu kompetensi juga menunjukkan karakteristik pengetahuan dan keterampilan yang dimiliki atau dibutuhkan oleh setiap individu yang memampukan mereka untuk melakukan tugas dan tanggung jawab mereka secara efektif dan meningkatkan standar kualitas profesional dalam pekerjaan mereka. Kompetensi menjelaskan apa yang dilakukan orang di tempat kerja pada berbagai tingkatan dan merinci standar masing-masing mengindentifikasi tingkatan, pengetahuan dan keterampilan yang diperlukan oleh individu yang memungkinkan menjalankan. Oleh sebab itulah, maka sumber daya manusia perlu memiliki kemampuan untuk berkembang secara rasional dan juga mempunyai kemampuan untuk berkembang secara terus menerus dan berkesinambungan, karena pegawai memberikan konstribusi yang sangat besar bagi organisasi dalam proses pencapaian tujuan yang telah ditetapkan. Selain kompetensi seorang pegawai faktor sarana prasarana dapat membantu dan mempermudah seseorang untuk lebih baik lagi dalam beraktivitas. Sarana dan prasarana merupakan bentuk fasilitas pelengkap terhadap penunjang akan aktivitas kerja. Karena tanpa adanya sarana dan prasarana seperti fasilitas kerja tersebut maka aktivitas kerja yang dilaksanakan di akan berjalan kurang baik. Menurut Komariah (2009:108-109) menjelaskan akan aktivitas para pegawai, di dalam kantor kelangsungannya pekerjaannya akan banyak dipengaruhi oleh kondisi dan situasi fisik, lingkungan dan fasilitas kerja yang tersedia. Oleh sebab itulah lingkungan fisik kantor berupa sarana dan prasarana harus dapat memenuhi dan mendukung interaksi 
yang terjadi, sehingga harmonisasi kehidupan kerja dapat berlangsung dengan baik dari permulaan masa kerja sampai akhir masa kerja. Guna menunjang kedua hal tersebut faktor perencanaan program dalam setiap aktivitas sangatlah penting karena dengan adanya perencanaan program tersebut akan dapat membantu dan mempermudahan serta mengarahkan aktivitas untuk dapat berjalan sesuai dengan yang ditetapkan dan sesuai dengan yang direncanakan. Farland (2011:78) menjelaskan perencanaan adalah seuatu proses pemilihan dan pengembangan dari tindakan yang paling baik untuk pencapaian tugas. Jadi dapat disimpulkan guna mencapai dan meningkatkan kualitas seseorang dalam bekerja atau kualitas dari sumber daya manusia itu banyak faktor yang mempengaruhinya, di antaranya yang menjadi pokok bahasan dalam penelitian ini adalah faktor kompetensi, sarana prasana maupun perencanaan dan program pelatihan. Dinas Tenaga Kerja dan Transmigrasi Kabupaten Balangan Kalimantan Selatan merupakan sebuah lembaga pemerintah daerah yang bergerak dalam bidang pengelolaan transmigrasi dan ketenagakerjaan, yang mana selama ini pihak instansi mempunyai wewenang dan tugas untuk selalu mengembangkan sumber daya manusia atau tenaga kerja yang ingin mencari lapangan kerja bagi bidang ketenagakerjaan untuk dapat meningkatkan kualitas tenaga kerja yang didiknya agar dapat bersaing dilapangan kerja atau bursa kerja, serta mendidik para peserta transmigrasi yang handal dalam mengeolah pemukiman agar menjadi lahan yang produktif dan berhasil mendidik masyarakat (para transmigrasi) dalam bertani dan berkebun, namun belum dapat dicapai sesuai dengan harapan. Observasi awal penulis terhadap aktivitas kerja pegawai Dinas Tenaga Kerja dan Transmigrasi Kabupaten Balangan Kalimantan Selatan di bidang tenaga kerja, dalam memberikan bekal pendidikan, keahlian dan keterampilan bagi calon tenaga kerja/pencari kerja di nilai belum maksimal, hal in idibuktikan dari kualitas tenaga kerja/para pencari kerja yang belum mampunya bersaing dan belum dapat mandiri dalam ruang kerja yang ada dilapangan kerja, hal ini selain faktor individu dari para tenaga kerja atau pencari kerja sendiri yang kurang baik, namun hal ini disebabkan pula karena kurang kemampuan pegawai memberikan pendidikan, keahlian dan keterampilan bagi para calon tenaga kerja atau pencari kerja. Selama ini kompetensi pegawai telihat dari masih kurang efektifnya penegakan peraturan kerja, penegakan disiplin, maupun kemampuan kerja kurang maksimal ini terlihat saat pegawai diserahi tanggung jawab sering kali kurang mampu menjalankan tugas, seperti belum mampu membuat perencanaan dan pelatihan kerja bagi para tenaga kerja yang dibina serta masih terdapat pegawai yang kurang menguasai teknologi dalam pekerjaannya, sehingga hal ini berdampak aktivitas pembinaan tenaga kerja menjadi kurang optimal. Peran serta dukungan yang baik dan profesional dari para pegawai dalam upaya meningkatkan kualitas tenaga kerja atau para calon pencari kerja sangatlah diharapkan guna menambah kompetensi dengan bekal keahlian dan keterampilan bagi para calon tenaga kerja atau pencari kerja. Selain itu bila dilihat dari aspek sarana prasarana yang dimiliki Dinas Tenaga Kerja dan Transmigrasi Kabupaten Balangan Kalimantan Selatan dalam menunjang kualitas tenaga kerja juga terdapat permasalahan yang kerap kali muncul dalam hal peningkatan kualitas para calon tenaga kerja atau pencari kerja, yakni sepertti terlihat kurangnya sarana prasarana yang dimiliki dalam memberikan pelatihan seperti protektor yang sebagian rusak, komputer yang tersedia terbatas tidak dapat menampung para peserta pelatihan mupun kapasitas ruang yang masih terlihat terbatas, sehingga hal ini sering menjadi kurang optimal dalam memberikan pengembangan kepada tenaga kerja yang didik, sehingga kerap kali kualitas tenaga kerja yang dikelola tidak sesuai dengan harapan. Bila dilihat dari aspek perencanaan program pelatihan terlihat selama ini penyusunan perencanaan program pelatihan terkesan kurang optimal, karena kadang calon tenaga 
kerja atau pencari kerja.waktu dan program pelatihan diberikan dengan waktu yang sebentar dan juga tanpa ada praktek secara langsung terhadap pelatihan yang diberikan selain itu program dari bahan pelatihan tidak habis di terangkan dalam pemberian materi sehingga keterampilan dan keahlian yang diterima tidak berjalan optimal. Sehubungan dengan hal itulah, maka penulis tertarik untuk mengadakan penelitian dengan pentingnya kompetensi, sarana prasarana dan perencanaan dan program pelatihan dalam menunjang kualitas tenaga kerja Dinas Tenaga Kerja dan Transmigrasi Kabupaten Balangan Kalimantan Selatan. Berdasarkan hal itulah, adapun tema judul dalam penelitian ini Analisis Kompetensi, Sarana Prasarana Dan Perencanaan Program Pelatihan Terhadap Kualitas Tenaga Kerja pada Dinas Tenaga Kerja Dan Transmigrasi Kabupaten Balangan Kalimantan Selatan.

\subsection{Rumusan Masalah}

Berdasarkan latar belakang yang telah penulis kemukakan tersebut, yang menjadi perumusan masalah dalam penelitian ini adalah :

1. Apakah kompetensi berpengaruh signifikan terhadap kualitas tenaga kerja pada Dinas Tenaga Kerja Dan Transmigrasi Kabupaten Balangan Kalimantan Selatan?

2. Apakah sarana prasarana berpengaruh signifikan terhadap kualitas tenaga kerja pada Dinas Tenaga Kerja Dan Transmigrasi Kabupaten Balangan Kalimantan Selatan?

3. Apakah perencanaan program pelatihan berpengaruh signifikan terhadap kualitas tenaga kerja pada Dinas Tenaga Kerja Dan Transmigrasi Kabupaten Balangan Kalimantan Selatan?

4. Apakah kompetensi, sarana prasarana dan perencanaan program pelatihan berpengaruh signifikan secara simultan terhadap kualitas tenaga kerja pada Dinas Tenaga Kerja Dan Transmigrasi Kabupaten Balangan Kalimantan Selatan?

\section{TINJAUAN PUSTAKA}

\subsection{Landasan Teori}

\subsubsection{Kompetensi}

Menurut Rivai, (2009:289) menjelaskan tentang kompetensi menyangkut kewenangan setiap individu untuk melakukan tugas atau mengambil keputusan sesuai dnegan perannya dalam organisasi yangrelevan dengan keahlian, pengetahuan, dan kemampuan yang dimiliki. Kompotensi yang dimiliki karyawan secara individu harus mampu mendukung pelaksanaan strategi organisasi/instansi dan mampu mendukung setiap peubahan yang dilakukan manajemen. Dengan kata lain kompetensi yang dimiliki individu dapat mendukung sistem kerja berdasarkan tim. Menurut Hutabarat (2007 : 297), kompetensi adalah suatu ilmu pengetahuan atau mengetahui bagaimana untuk melakukan kerja yang efektif. Ukas (1999:245) menyatakan bahwa kompetensi adalah daya kesanggupan di dalam menggerakan orang dan menggerakan fasilitas dalam suatu organisasi, nilai ini dalam manajemen sangat menentukan oleh karena nilai demikian berkenaaan dengan aktivitas pokok yaitu memimpin suatu organisasi yang bersangkutan. Ginting (2000:98) kompetensi adalah kemampuan atau keahlian pimpinan untuk menjalankan fungsi manajemen. Dalam bidang manajemen, faktor kemampuan manajerial sangat penting dan menentukan, karena faktor tersebut berkaitan dengan aktivitas pokok suatu organisasi yaitu memimpin organisasi yang bersangkutan dalam usahanya mencapai tujuan.

Menurut Davis (1999:299) kompetensi adalah sebuah kemampuan perspektif dan pengetahuan manuasi, khususnya untuk mempengaruhi kemampuan untuk kebutuhan dalam sebuah bisnis melalui biaya minimal dan servis yang optimal kepada pelanggan tanpa kecuali. Menurut Wibowo, (2010:266) kompetensi adalah kemampuan seseorang untuk menghasilkan pada tingkat kepuasan ditempat kerja, termasuk diantaranya kemampuan seseorang untuk mentransfer dan mengaplikasikan keterampilan dan pengatahuan tersebut dalam situasi yang 
baru dan meningkatkan manfaat yang disepakati. Selain itu kompetensi juga menunjukkan karakteristik pengetahuan dan keterampilan yang dimiliki atau dibutuhkan oleh setiap individu yang memampukan mereka untuk melakukan tugas dan tanggung jawab mereka secara efektif dan meningkatkan standar kualitas profesional dalam pekerjaan mereka. Kompetensi menjelaskan apa yang dilakukan orang di tempat kerja pada berbagai tingkatan dan merinci standar masing-masing tingkatan, mengindentifikasi karakteristik, pengetahuan dan keterampilan yang diperlukan oleh individu yang memungkinkan menjalankan. Kemudian menurut Basri, dkk, (2009:298) menjelaskan kompetensi secara umum diartikan sebagai kecakapan, keterampilan, kemampuan. Kata dasarnya sendiri yaitu kompeten, tentu saja berarti cakap, mampu, atau terampil. Pada konteks manajemen SDM istilah konpetensi mengacu kepada atribut/karakteristik seseorang yang membuatnya berhasil dalam pekerjaannya. Kompetensi menurut Sagala (2009:299) menjelasakan bhawa kompetensi bisa dianalogikan seperti 'gunung es' dimana keterampilan dan pengetahuan membentuk puncaknya yang berada diatas air. Bagian yang ada dibawah permukaan air tidak terlihat dengan mata telanjang, namun menjadi fondasi dan memiliki pengaruh terhadap bentuk dari bagian yang berada diatas air. Peran sosial dan citra berada pada bagian 'sadar' seseorang, sedangkan trait dan motif seseorang berada pada alam 'bawah sadarnya'. Berikut adalah penjelasan tentang kompoetensi, yaitu (1) keterampilan meliputi keahlian/kecakapan melakukan sesuatu dengan baik (2) pengetahuan meliputi informasi yang dimiliki/ dikuasai seseorang dalam bidang tertentu (3) peran sosial meliputi citra yang diproyeksikan seseorang kepada orang lain (4) citra diri meliputi persepsi individu tentang dirinya (5) trait merupakan karakater yang relatif konstan pada tingkah laku seseorang (6) motif merupakan pemikiran atau niat dasar yang konstan yang mendorong individu untuk bertindak atau berperilaku.

Menurut Zohar \& Marshall dalam Susilo (2003:3) menyatakan manusia memiliki tiga dimensi, yaitu fisik, emosi dan spiritual. Dan atas dasar dimensi ini lalu mereka mengelompokan kompetensi menjadi tiga, yaitu kompetensi Intelektual, kompetensi emosional dan kompetensi spiritual. Menurut Handoko (2010:113) dilihat dari aspek hubungan antar personal maka diperlukan kemampuan dan kemauan untuk menjalin hubungan harmonis dengan orang lain, yang disebut dengan kompetensi sosial.

Kemudian menurut Zohar dan Marshall dalam Susilo (2003:3) mengklasifikasikan dimensi dan komponen kompetensi individual menjadi tiga, yaitu:

a. Kompetensi Intelektual adalah kemampuan dan kemauan yang berkaitan dengan pemecahan masalah yang bersifat rasional dan strategik. Kompetensi intelektual adalah kemampuan yang di perlukan untuk menjalankan kegiatan mental.

b. Kompetensi Emosional adalah kemampuan belajar berdasarkan pada kecerdasan emosional yang menghasilkan kinerja di tempat bekerja.

c. Kompetensi Spiritual adalah karakter sikap yang merupakan bagian dari kesadaran yang paling dalam pada seseorang yang berhubungan dengan kebijaksanaan/kearifan yang berasal dari luar ego (diri sendiri) atau di luar pemikiran sadar yang tidak hanya mengakui keberadaan nilai tetapi juga kreatif untuk menemukan nilia-nilai baru.

Riyanto (2010:70) menemukan 15 unsur dalam kompetensi para pegawai, yaitu oentasi pencapaian prestasi, pkiran analitis, memiliki kemampuan dalam berhadapan dengan keadaan serba tidak pasti, pengambilan keputusan, kepemimpinan, kerja jejaring, komunikasi lisan, dorongan pribadi dan Inisiatif, kemampuan untuk membujuk, perencanaan dan pengorganisasian, kepedulian terhadap halhal yang bersifat politik, kesadaran terhadap diri sendiri dan pengembangan diri, kerja 
kelompok, tingkatan pengetahuan dan keterampilan yang dimiliki dan komunikasi tertulis.

Menurut Husnan, (2000:77) menjelaskan untuk meningkatkan keterampilan dan kompetensi dair pegawai perlu adanya latihan adalah kegiatan untuk meningkatkan pengetahuan umum seseorang termasuk di dalamnya peningkatan penguasaan teori dan keterampilan memutuskan terhadap persoalan yang menyangkut kegiatan mencapai tujuan. Setiap organisasi/instansi yang menginginkan karyawannya dapat bekerja secara lebih efektif dan efisien sama sekali tidak boleh meremehkan masalah pelatihan ini. memang ada beberapa karyawan yang mampu memotivasi diri sendiri untuk dapat meningkatkan kemampuan dirinya tanpa campur tangan dari organisasi/instansi yang bersangkutan, namun dalam kenyataan jumlah karyawan yang mampu memotivasi diri sendiri adalah sangat sedikit. Oleh sebab itulah baik karyawan lama dan karyawan yang sudah berpengalaman maupun karyawan baru perlu sekali diberikan pelatihan. Dengan pelatihan diharapkan pekerjaan dapat dilakukan secara lebih baik, karena di dalam pelatihan tersebut mempunyai beberapa sasaran utama yang ingin di capai. Nitisemito, (2011, 65-69) mengemukakan beberapa cara atau sistem pelatihan, yaitu sebagai berikut:

a) Sistem magang, merupakan sisten pelatihan yang dilakukan dengan belajar sambil bekerja.

b) Sistem ceramah/kuliah merupakan sistem pelatihan yang dilaukan melalui komunikasi satu arah dari atas ke bawahan.

c) Sistem peragaan merupakan sistem pelatihan yang dilakukan dengan keterampilan tertentu menggunakan alat bantu dengan cara di demosntrasikan.

d) Sistem bimbingan merupakan sistem pelatihan yang dilaksanakan dengan pembelajaran secara langsung yang diberikan satu persatu.

e) Sistem diskusi merupakan bentuk pelatihan yang dilakukan dengan diskusi melalui lokakarya, rapat seminar dan lain sebaginya hal ini penting karena dapat mengemukakan argementasi.

f) Sistem permainan merupakan sistem pelatihan yang dirancang dalam bentuk permainan, dalam hal ini banyak menekankan dalam psikologi

g) Sistem kombinasi merupakan pelatihan yang mengkombinasikan semua cara pelatihan yang sesuai dengan kondisi perusahaan.

\subsubsection{Sarana Prasarana}

Sarana dan prasarana merupakan bentuk fasilitas pelengkap terhadap penunjang akan aktivitas kejra. Karena tanpa adanya sarana dan prasarana seperti fasilitas kerja tersebut maka aktivitas kerja yang dilaksanakan di akan berjalan kurang baik. Menurut Komariah (2009:108-109) menjelaskan akan aktivitas para pegawai, di dalam kantor kelangsungannya pekerjaannya akan banyak dipengaruhi oleh kondisi dan situasi fisik, lingkungan dan fasilitas kerja yang tersedia. Oleh sebab itulah lingkungan fisik kantor berupa sarana dan prasarana harus dapat memenuhi dan mendukung interaksi yang terjadi, sehingga harmonisasi kehidupan kerja dapat berlangsung dengan baik dari permulaan masa kerja sampai akhir masa kerja. Sarana adalah peralatan dan perlengkapan yang secara langsung dipergunakan dan menunjang proses kerja, seperti gedung, ruang kerja, meja, kursi, serta alat-alat dan media elektronik. Adapun yang dimaksud dengan prasarana adalah fasilitas yang secara tidak langsung menunjang jalannya proses kerja, seperti halaman, kantin, taman, lapangan upacaran, lapangan olahraga. Mulyasa, (2007: 49) sarana dan prasarana/fasilitas kerja adalah perlengkapan yang diperlukan untuk menyelenggarakan pekerjaan yang dapat dipindah-pindah. Prasarana adalah fasilitas dasar yang diperlukan untuk menjalankan fungsi satuan kerja. Moenir (2002:119) menjelaskan sarana dan prasarana adalah segala jenis peralatan, perlengkapan kerja dan fasilitas yang berfungsi sebagai alat utama/pembantu dalam pelaksanaan pekerjaan, yang keduanya berfungsi untuk mewujudkan tujuan yang hendak dicapai. Berta (2011:95) menjeleaskan 
tentang sarana adalah segala sesuatu yang dapat dipakai sebagai alat dalam mencapai maksud atau tujuan, sedangkan prasarana adalah segala sesuatu yang merupakan penunjang utama terselenggaranya suatu proses atau aktivitas. Dewi (2012:210) menjelaskan sarana merupakan segala sesuatu yan dapat digunakan sebagai alat dalam mencapai suatu maksud dan tujuan. Artinya sarana mengarah pada benda atau alay ang bergerak. Contoh saranapada suatu kantor seperti komputer, meja, kursi, dokumen, rak, papa tulis dan lain-lain. Sedangkan prasarana merupakan segala sesuatu yang menjadi penunjang utama terseleggaranya sutu proses. Proses tersebut dapat berupa suatu pembangunan, usaha, ataupun proyek. Contoh prasarana untuk kantor adalah gedung, ruang kerja, ruang rapat, tanah lapang dan lain-lain. Setiawan (2010:88) menjelaskan sarana adalah segala sesuatu yang dapat dipakaisebagai alat dan bahan untuk mencapai maksud dan tujuan dari suatu proses kerja. Prasarana adalah segala sesuatu yang berguna untuk menunjang atau alat penunjang utama dalam proses maupun terselanggarannya aktivitas kerja. Selain itu juga Komariah (2009:109) menjalaskan kreteria minimal untuk melengkapi sarana dan prasarana didalam mencakup rasa aman, estetika, sehat, cukup, bermutu, dan nyaman yang terpenting pula dengan fasilitas yang minim dapat diatur dengan baik sehingga daya gunanya lebih tinggi. Pengaturan fasilitas tersebut adalah:

1. Fasilitas mengatur orang yaitu berhubungan dengan memberikan sarana penunjang terhadap perbaikan tingkah laku, kedisiplinan, minat dan perhatian, gairah kerja, dan dinamika kelompok.

2. Fasilitas kerja yaitu berhubungan dengan memberikan sarana penunjang terhadap perbaikan ventilasi, pencahayaan, kenyamanan, letak duduk, dan penempatan kerja.

Soermano (2010:76) menjelaskan fungsi utama dari sarana prasarana adalah:
a. Menciptakan kenyamanan
b. Menciptakan kepuasan
c. Mempercepat proses kerja
d. Memudahkan proses kerja

e. Meningkatkan produktivitas

f. Hasil lebih berkualitas

Moenir (2002:124) menjelaskan akan pembagian dari sarana prasarana sebagai berikut:

1) Peralatan kerja yaitu semua jenis benda yang berfungsi sebagai alat pembantu tidak langsung dalam pekerjaan atau produks, mempercepat proses, membangkit dan menambah kenyamanan dalam pekerjaan.

2) Perlengkapan kerja yaitu semua jenis benda yang berfungsi sebagai alat pembantu tidak langsung dalam proses pekerjaan, mempercepat proses, membangkit dan menambah kenyamanan dalam pekerjaan

3) Pelengkapan bantu atau fasilitas yaitu semua jenis benda yang berfungsi membantu kelancaran gerak dalam pekerjaan.

\subsubsection{Perencanaan Program Pelatihan}

Perencanaan akan terdapat aktivitas pengujian beberapa arah pencapaian, mengkaji ketidakpastian, mengukur kapasitas, menentukan arah pencapaian, serta menentukan langkah untuk mencapainya. Perencanaan adalah salah satu fungsi dari manajemen yang paling penting dimana di dalamnya terdapat aktivitas mendefinisikan tujuan organisasi, membuat strategi, serta mengembangkan rencana kerja organisasi. Perencanaan adalah tahap awal dalam kegiatan suatu organisasi terkait dengan pencapaian tujuan organisasi tersebut. Kecakapan pegawai dimaksudkan sebagai suatu usaha dari pimpinan untuk menambah keahlian kerja, sehingga dalam melaksanakan tugastugasnya dapat lebih berkualitas. Jadi jelas bahwa pengembangan kecakapan tenaga kerja merupakan tanggung jawab pimpinan. Adapun salah satu cara mengembangkan kecakapan pegawai tersebut adalah melalui program diklat atau pendidikan dan latihan. Diklat merupakan salah satu faktor yang penting dalam menciptakan sumber daya manusia yang berkualitas. Pendidikan dan pelatihan dilaksanakan setelah terjadi penerimaan tenaga kerja, sebab pendidikan dan pelatihan hanya diberikan pada tenaga kerja dari perusahaan yang bersangkutan. 
Adakalanya pelatihan diberikan sebelum dan ada juga sesudah tenaga kerja tersebut ditempatkan. Hal ini tergantung pada kebijaksanaan organisasi itu sendiri, maka yang lebih baik menurut pertimbangan manajemen yang bersangkutan. Latihan membantu tenaga kerja dalam memahami suatu pengetahuan praktis dan penerapannya guna meningkatkan keterampilan, kecakapan, dan sikap yang diperlukan oleh organisasi dalam mencapai tujuan. Pada dasarnya latihan melengkapi pendidikan. Pendidikan biasanya bersifat umum, sedangkan latihan bersifat khusus dan teknik operasional. Sebab itu latihan kerja diperlukan bukan saja sebagai pelengkap pendidikan akan tetapi justru sekaligus untuk memberikan dasar-dasar pengetahuan.

Menurut Erly Suandy (2001:2), pengertian perencanaan adalah suatu proses penentuan tujuan organisasi dan kemudian menyajikan dengan jelas strategi-strategi, taktik-taktik, dan operasi yang diperlukan untuk mencapai tujuan organisasi secara menyeluruh. Menurut Becker (dalam Rustiadi 2008:339), pengertian perencanaan adalah suatu cara rasional untuk mempersiapkan masa depan.Hartanto (2012:103) menjelaskan perencanaan adalah suatu proses atau cara berpikir yang dapat membantu menciptakan hasil yang diharapkan, selain itu perencanaan merupakan proses penyusunan berbagai keputusan yang akan dilaksanakan dalam mencapai suatu tujuan yang telah ditetapkan. Sutrisno (2011:88) menjelaskan perencanaan merupakan faktor penting dalam sebuah program diklat. Perencanaan yang baik akan dapat membantu lembaga penyelenggara dalam melaksanakan kegiatnnya dengan terpadu sehingga dapat mencapai hasil yang maksimal. Menurut Alder (dalam Rustiadi 2008:339), pengertian perencanaan adalah suatu proses menentukan apa yang ingin dicapai di masa yang akan datang serta menetapkan tahapan-tahapan yang dibutuhkan untuk mencapainya. Menurut Douglas (2009:153) definisi perencanaan adalah suatu proses kontinu dari pengkajian, membuat tujuan dan sasaran, dan mengimplementasikan serta mengevaluasi atau mengontrolnya.Jadi dapat disimpulkan perencanaan adalah suatu proses memulai dengan sasaran-sasaran, batasan strategi, kebijakan, dan rencana terperinci untuk mencapainya, mencapai organisasi untuk menerapkan keputusan, dan termasuk tinjauan kinerja dan umpan balik terhadap pengenalan siklus perencanaan baru. Menurut Soermano (2010:100) menjelaskan tujuan perencanaan diklat:

a. Menentukan secara sistematis tahapan kegiatan diklat yang akan dilaksanakan

b. Menentukan aspek-aspek atau unsur yang menjadi focus pada pelaksanaan diklat

c. Menentukan model yang digunakan dalam desain diklat

d. Menentukan bahan, media, metode yang digunakan dalam pelaksanaan diklat

Pelatihan juga sangat perlu direncanakan jauh hari sebelumnya, agar kegiatan pelatihan tidak menjadi sia-sia apalagi sampai membuang segala waktu, uang dan terbengkalainya pekerjaan yang lainnya. untuk itu pelatihan SDM harus dimasukkan ke dalam program dengan perencanaan yang baik oleh pihak manajemen.

Latihan membantu tenaga kerja dalam memahami suatu pengetahuan praktis dan penerapannya guna meningkatkan keterampilan, kecakapan, dan sikap yang diperlukan oleh organisasi dalam mencapai tujuan. Pada dasarnya latihan melengkapi pendidikan. Pendidikan biasanya bersifat umum, sedangkan latihan bersifat khusus dan teknik operasional. Sebab itu latihan kerja diperlukan bukan saja sebagai pelengkap pendidikan akan tetapi justru sekaligus untuk memberikan dasar-dasar pengetahuan. Menurut Handoko, (2010:104) latihan adalah suatu kegiatan yang bermaksud untuk penguasaan berbagai keterampilan dan teknik pelaksanaan kerja tertentu, terinci, dan rutin. Yang pada prinsipnya pelatihan digunakan untuk menyiapkan karyawan untuk melakukan pekerjaan sekarang. Nitisemito, (2011:53) menjelaskan pelatihan atau training adalah suatu kegiatan yang bermaksud untuk memperbaiki dan mengembangkan sikap, 
tingkah laku, keterampilan, dan pengetahuan dari karyawan sesuai dengan keinginan perusahaan.

Sedangkan menurut Husnan, (2009:77) latihan adalah kegiatan untuk meningkatkan pengetahuan umum seseorang termasuk didalamnya peningkatan penguasaan teori dan keterampilan memutuskan terhadap persoalan-persoalan yang menyangkut kegiatan mencapai tujuan.

Jadi berdasarkan penjelasan tersebut dapat disimpulkan bahwa diklat (pendidikan dan latihan) adalah proses membantu para pegawai untuk memperoleh efektivitas dalam pekerjaan mereka yang sekarang atau yang akan datang melalui peningkatan kebiasaan-kebiasaan tentang pikiran, tindakan, kecakapan, pengetahuan, dan sikap yang positip.

Dengan pelatihan dan pendidikan diharapkan pekerjaan dapat dilakukan secara lebih baik, karena didalam pelatihan tersebut mempunyai beberapa sasaran utama yang ingin dicapai. Melihat dari pentingnya pelatihan bagi peningkatan kerja karyawan, maka guna menunjang kegiatan pelatihan tersebut dapat digunakan setiap perusahaan agar dapat dilaksanakan sesuai dengan kebutuhan dan kemampuan perusahaan.

Nitisemito (2011:57) menjelaskan pula tentang keuntungan dari adanya pelatihan dan pendidikan bagi karyawan, yaitu mengurangi pengawasan, meningkatkan kerjasama antar karyawan, meningkatkan rasa harga diri, memudahkan pelaksanaan promosi dan mutasi, memudahkan pelaksanaan pendelegasian wewenang. Pelatihan merupakan kebijaksanaan yang sangat penting untuk dapat diterapkan oleh pihak instansi agar dapat membantu operasional perusahaan, karena dengan adanya pelatihan dan pendidikan pengetahuan dan keterampilan karyawan dapat diperbaiki dan dapat ditingkatkan yang akhirnya dapat memberikan nilai yang positip terhadap operaisonal organisasi. Dalam aktivitas kegiatan latihan ada beberapa teknik dan metode yang dapat dilaksanakan agar dapat mensukseskan kegiatan operasional dalam meningkatkan kualitas kerja karyawan. Hal ini dapat dilihat dari fungsi dan tujuan pendidikan serta pelatihan oleh sebab itulah perlu adanya teknik atau metode dalam pelaksanaannya. Pendidikan dan Pelatihan Pegawai menurut PP No. 101 Tahun 2000 dinyatakan Pendidikan dan Pelatihan Jabatan Pegawai Negeri Sipil yang selanjutnya disebut Diklat adalah penyelenggaraan proses belajar mengajar dalam tangka meningkatkan kemampuan pegawai negeri sipil yang mengacu pada kompetensi jabatan. Karena itu misi Diklat menurut PP no. 101 tahun 2000, bahwa setiap pelatihan yang dilaksanakan harus memberikan kompetensi kepada pesertanya. Beberapa point penting mengenai kompetensi ini antara lain setiap alumni diklat diharapkan :

a. Mampu memberikan pelayanan prima terhadap publik sesuai dengan tugas dan tanggung jawab unit organisasi.

b. Mampu melaksanakan pengorganisasian dalam rangka pelaksanaan tugas dan tanggung jawab unit organisasi

c. Mampu membangun jaringan kerja / melakukan kerjasama dengan unit-unit terkait baik dalam organisasi maupun duliar organisasi untuk meningkatkan kinerja organisasi.

d. Mampu melakukan koordinasi, integrasi dan sinkronisasi dalam unit organisasi.

e. Mampu menumbuhkembangkan, inovasi, kreasi dan motivasi pegawai untuk mengoptimalkan kinerja unit organisasi.

Tujuan Diklat Pegawai Negeri sipil adalah :

1) Meningkatkan pengetahuan, keahlian, keterampilan dan sikap untuk dapat melaksanakan tugas jabatan secara profesional dengan dilandasi kepribadian dan etika pegawai negeri sipil dengan kebutuhan instansi.

2) Menciptakan aparatur yang mampu berperan sebagai perubahan dan perekat persatuan dan kesatuan bangsa.

3) Memantapkan sikap dan semangat pengabdian yang berorientasi pada pelayanan, pengayoman dan pemberdayaan masyarakat.

4) Menciptakan kesamaan visi dan dinamika pola pikir dalam melaksanakan tugas pemerintahan umum dan 
pembangunan demi terwujudnya kepemerintahan yang baik.

Handoko, (2001,112-116) menjelaskan akan teknik latihan, yaitu sebagai berikut:

a. Metode praktis (on the job training) Teknik on the job merupakan metode latihan dan pendidikan yang paling banyak digunakan.

b. Metode simulasi (off the job training), yaitu metode atau pendekatan ini karyawan dilatih menerima presentasi suatu aspek organisasi dan diminta untuk menanggapi seperti dalam keadaan sebenarnya.

\subsubsection{Kualitas Tenaga Kerja}

Tenaga kerja merupakan faktor pendukung perekonomian suatu Negara. Untuk memajukan perekonomian suatu Negara diperlukan tenaga kerja yang berkualitas. Dalam suatu Negara, tenaga kerja ada yang dipekerjakan di dalam dan di luar Negara itu sendiri. Seperti halnya Indonesia, tenaga kerja Indonesia banyak bekerja di luar negeri. Tenaga kerja Indonesia yang bekerja di luar negeri, dapat menghasilkan devisa Negara yang turut mendukung perekonomian Indonesia. Sehingga mereka dikenal dengan istilah pahlawan devisa Negara. Menurut UU No. 13 Tahun 2003, tenaga kerja adalah setiap orang yang mampu melakukan pekerjaan guna menghasilkan barang dan atau jasa untuk memenuhi kebutuhan sendiri maupun masyarakat. Tenaga kerja dapat juga diartikan sebagai penduduk yang berada dalam batas usia kerja. Tenaga kerja disebut juga golongan produktif, yakni dari usia 1565 tahun.

Brotoharsojo (2013:57) menjelaskan kualitas dapat dinayatakan dalam suatu ukuran yang dapat dipadankan dengan angka.

Makmur (2009:90) kualitas adalah tingkat atau taraf baik atau buruk derajat seseorang dalam beraktivitas maupun dalam bekerja dalam sebuah organisasi. Wilson dan Heyel (1987) dalam Brotoharsojo (2013:65) menjelaskan kualitas kerja adalah mutu seseorang karyawan atau pegawai dalam melaksanakan tugas-tugasnya, meliputi kesesuaian, kerapia, keahlian, kemampuan dan kelengkapan lain dalam beraktivitas dan bekerja.

Hartano (2011:123) menjelaskan kulitas kerja adalah suatu hasil yang bisa diukur dari tingkat efesiensi dan efektifitas seseorang dalam bekerja atau dalam melaksanakan suatu pekerjaan yang didukung oleh sumber daya lainnya dalam mencapai tujuan perusahaan secara umum. Matutina,(2001:200), menjelaskan pengertian dari kualitas kerja adalah suatu standar fisik yang diukur karean hasil kerja yang dilakukan atau dilaksanakan karyawan atas tugas-tugasnya. Inti dari kualitas kerja adalah suatu hasil yang dapat diukur dengan efesiensi da efektivitas suatu pekerjaan yang dilakukan oleh karyawan atau pegawai dalam mencapau tujuan atau sasaran organisasi dengan baik dan berdaya guna.

Kualitas kerja mengacu pada kualitas sumber daya manusia (Matutina,2001:205), kualitas sumber daya manusia mengacu pada :

1) Pengetahuan (knowledge) yaitu kemampuan yang dimiliki karyawan yang lebih berorientasi pada intelejensi dan daya fikir serta penguasaan ilmu yang luas yang dimiliki karyawan.

2) Keterampilan (skill), kemampuan dan penguasaan teknis operasional di bidang tertentu yang dimiliki karyawan.

3) Abilities yaitu kemampuan yang terbentuk dari sejumlah kompetensi yang dimiliki seorang karyawan yang mencakup loyalitas, kedisiplinan, kerjasama dan tanggung jawab.

Matutina,(2001:223) penyebab kualitas tenaga kerja Indonesia rendah, adalah sebagai berikut:

1) Rendahnya tingkat penguasaan teknologi

2) Terbatasnya fasilitas dan infrastruktur

3) Kemampuan bekerja keras yang rendah

4) Faktor Usia

\subsection{Penelitian Terdahulu}

Dalam menunjang penelitian perlu adanya litaratur berupa peneliti terdahulu yang dapat memberikan tolak ukur dalam penelitian ini, adapun penelitian terdahulu terkait dengan materi yang sama dengan penelitian yang dilakukan sekarang oleh 
penulis, maka dapat dijelaskan sebagai berikut:

1. Eka Putri, 2012, dengan judul penelitian Pengaruh Kompetensi, Diklat dan Sarana prasarana Terhadap Kualitas Pegawai Pada Dinas Kesehatan Kota Banjarmasin, dalam penelitiannya menggunakan populasi sebanyak 87 dan ditentukan jumlah sampelnya sebanyak 87 atau semua jumlah populasi dijadikan sampel. Alat uji yang digunakan dalam penelitian tersebutregresi berganda dengan alat uji seperti uji Instrumen Uji Asumsi Klasik Uji Regresi Semua variabel bebas mempunyai pengaruh signifikan baik secara parsial maupun simultan dan yang berpengaruh dominan adalah variabel profesionalisme Persamaannya Sama bidang SDM, Sama dalam penggunaan alat uji Perbedaan obyek yg diteliti. Populasi yg gunakan Sebagian variabel yang digunakan.

2. Setiawan, 2013, Pengaruh Kompetensi, Pelatihan Terhadap Kinerja Pegawai Pada Kantor BNN Kabupaten Balangan, dalam penelitiannya menggunakan populasi sebanyak 51 orang dan sampel ditentukan sebanyak 51 responden dengan analisis reresi berganda dengan alat uji sebagai berikut : uji Instrumen Uji Asumsi Klasik Uji Regresi Semua variabel bebas mempunyai pengaruh signifikan baik secara parsial maupun simultan dan yang berpengaruh dominan adalah variabel budaya organisasi Persamaannya :Sama bidang SDM, Sama dalam penggunaan alat uji. Perbedaan Obyek yg diteliti, Populasi yg gunakan sebagian variabel yang digunakan.

3. Emmy Sopyan, 2012, Pengaruh Kompetensi, Saran prasarana, Program Pelatihan Terhadap Kualitas Pegawai Pada Kantor Dinas Pendapatan Kota Banjarmasin, dalam penelitiannya menggunakan populasi sebanyak 50 dan sampel sebanyak 50, dengan analisis regresi berganda dengan alat uji yang di pakai adalah uji Instrumen Uji Asumsi Klasik Uji Regresi Semua variabel bebas mempunyai pengaruh signifikan baik secara parsial maupun simultan dan yang berpengaruh dominan adalah variabel budaya organisasi Persamaannya :Sama bidang SDM, Sama dalam penggunaan alat uji. Perbedaan Obyek yg diteliti, Populasi yg gunakan sebagian variabel yang digunakan

\section{KERANGKA KONSEPTUAL DAN HIPOTESIS}

\subsection{Kerangka Konseptual}

Kerangka konsep dalam penelitian ini adalah suatu variabel merupakan segala yang membedakan atau membawa variasi pada nilai, selain itu guna menjelaskan hubungan keterkaitan antar variabel bebas (variable independent) dengan variabel terikat (variable dependent), baik secara positif maupun secara negatif. Besarnya pengaruh yang ditimbulkan oleh variable bebas (variable independent) ini secara otomatis juga akan mempengaruhi nilai variable terikat (variable dependent). Berdasarkan hal tersebut dapat dijelaskan hubungan antar variabel dalam penelitian ini dapat dilihat melalui kerangka konseptual berikut ini, yaitu:

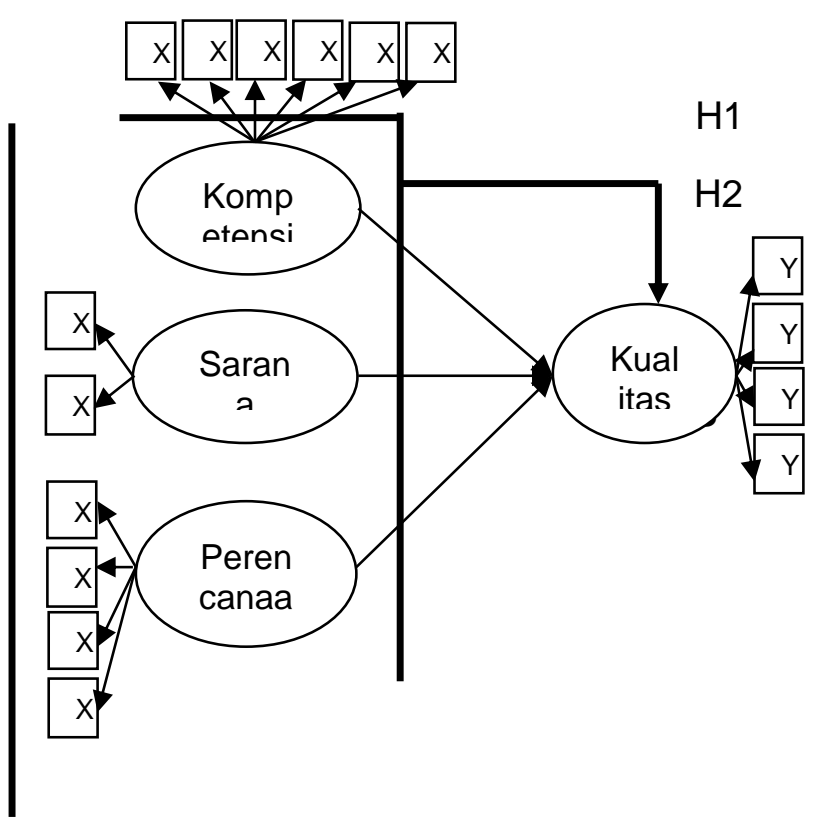


Gambar 3.1 : Kerangka Konseptual Sumber : Data Diolah Keterangan :

Pengaruh secara simultan
Pengaruh secara parsial

\subsection{Hipotesis Penelitian}

Berdasarkan permasalahan serta kerangka disebutkan diatas, maka hipotesis (dugaan sementara) yang diajukan dalam penelitian ini adalah:

1. Kompetensi berpengaruh signifikan terhadap kualitas tenaga kerja pada Dinas Tenaga Kerja Dan Transmigrasi Kabupaten Balangan Kalimantan Selatan.

2. Sarana prasarana berpengaruh signifikan terhadap kualitas tenaga kerja pada Dinas Tenaga Kerja Dan Transmigrasi Kabupaten Balangan Kalimantan Selatan.

3. Perencanaan program pelatihan berpengaruh signifikan terhadap kualitas tenaga kerja pada Dinas Tenaga Kerja Dan Transmigrasi Kabupaten Balangan Kalimantan Selatan.

4. Kompetensi, sarana prasarana dan perencanaan program pelatihan berpengaruh signifikan secara simultan terhadap kualitas tenaga kerja pada Dinas Tenaga Kerja Dan Transmigrasi Kabupaten Balangan Kalimantan Selatan.

\section{METODE PENELITIAN}

\subsection{Rancangan Penelitian}

Guna mempermudah pemahaman terhadap alur cerita dalam penelitian ini, maka perlu adanya penjelasan terhadap rancangan penelitian yang digunakan. Rancangan penelitian menjelaskan akan konsep dasar dalam penelitian ini, dimana rancangan penelitian ini merupakan suatu penelitian yang berbentuk infresial dengan menggunakan pendekatan positifistik, yaitu pendekatan yang menggunakan pola pikir edukatif dengan melihat gejala-gejala umum kemudian di lanjutkan kehal-hal yang lebih khusus, di mana data yang dikumpulkan dari hasil kuisioner dari para pegawai yang menggambarkan dan menjelaskan tentang pengaruh kompetensi (X1), sarana prasarana (X2) dan perencanaan program pelatihan (X3) terhadap kualitas tenaga kerja $(\mathrm{Y})$.

\subsection{Definisi Operasional Variabel}

Dalam penelitian ini para responden di minta untuk mengisi kuesioner yang secara garis besar dibagi dalam dua kelompok variabel yang menggambarkan latar belakang responden dan variabel motivasi komunikasi kerja. Penguraian definisi operasional variabel yang diteliti

1. Kompetensi (X1) adalah sebagai kecakapan, keterampilan, kemampuan. Kata dasarnya sendiri yaitu kompeten, tentu saja berarti cakap, mampu, atau terampil. Pada konteks manajemen SDM istilah kompetensi mengacu kepada atribut/karakteristik seseorang yang membuatnya berhasil dalam pekerjaannya.

2. Sarana prasarana (X2) adalah perlengkapan yang diperlukan untuk menyelenggarakan pekerjaan yang dapat dipindah-pindah.

3. Perencanan dan program pelatihan (X3) adalah proses membantu para pegawai untuk memperoleh efektivitas dalam pekerjaan mereka yang sekarang atau yang akan datang melalui peningkatan kebiasaan-kebiasaan tentang pikiran, tindakan, kecakapan, pengetahuan, dan sikap yang positip.

4. Kualitas tenaga kerja (Y) yaitu hasil pekerjaan seorang karyawan selama periode tertentu dibandingkan dengan berbagai kemungkinan, misalnya standar, target/sasaran/kriteria yang telah ditentukan terlebih dahulu dan telah disepakati bersama.

\subsection{Jenis dan Sumber data Penelitian}

\subsubsection{Jenis Data}

Adapun jenis data dalam penelitian ini yang penulis ambil, yaitu sebagai berikut:

1. Data Kualitatif, yaitu berupa data atau informasi yang tidak berbentuk angka. Penulis mengangkat data tersebut dari hasil wawancara, yakni berupa data 
tentang sejarah instansi, struktur organisasi, bidang operasional Dinas Tenaga Kerja dan Transmigrasi Kabupaten Balangan Kalimantan Selatan yang dilakukan atau proses kerja.

2. Data Kuantitatif yaitu data yang berbentuk angka, yang diangkat dari dokumen instansi dalam hal ini tentang data jumlah pegawai, data tabulasi dan data lain yang berhubungan dengan penelitian Dinas Tenaga Kerja dan Transmigrasi Kabupaten Balangan Kalimantan Selatan.

\subsubsection{Sumber Data}

Sumber data dalam penelitian ini terdiri dari sumber data primer dan sumber data sekunder, adapun uraian data sumber data tersebut, yaitu:

1. Data Primer merupakan data penelitian yang diperoleh secara langsung dari sumber asli secara khusus di kumpulkan oleh peneliti pada Dinas Tenaga Kerja dan Transmigrasi Kabupaten Balangan Kalimantan Selatan untuk menjawab pertanyaan yang diajukan melalui daftar pertanyaan.

2. Data Sekunder merupakan data penelitian yang diperoleh secara tidak langsung melalui media perantara seperti informasi dan publikasi atau laporan historis di Dinas Tenaga Kerja dan Transmigrasi Kabupaten Balangan Kalimantan Selatan yang telah tersusun dalam dokumen/arsip.

\subsection{Populasi dan Sampel}

\subsubsection{Populasi}

Populasi merupakan seluruh total responden yang menjadi indikator penelitian. Arikunto, (2006:102) menjelaskan akan pengertian dari populasi adalah keseluruhan subyek penelitian. Populasi dari penelitian ini adalah tenaga kerja yang ikut pelatihan di Dinas Tenaga Kerja dan Transmigrasi Kabupaten Balangan Kalimantan Selatan yang berjumlah 224 orang.

\subsubsection{Sampel}

Sugiono, (2009:56) sampel adalah sebagian dari jumlah dan karakteristik yang dimiliki oleh suatu populasi. Sampel harus betulbetul representative agar peneliti tidak mengambil kesimpulan salah. Arikunto,
(2006:89) apabila populasi kurang dari 100, maka semua akan menjadi sampel, jika populasi lebih dari 100, maka akan diambil $5 \%$ - $10 \%$ atau 20\%-25\% dari jumlah populasi. Sedangkan teknik penentuan sampel dalam penelitian ini menggunakan sensus dan berdasarkan nilai presentasi tersebut, maka jumlah sampel ditentukan sebanyak 56 orang responden atau sebanyak $25 \%$ dari jumlah populasi.

\subsection{Teknik Pengumpulan Data}

1. Studi kepustakaan, yaitu pengumpulan data melalui atau mempelajari berbagai literatur dan bahan bacaan yang berhubungan dengan permasalahan yang akan dibahas.

2. Observasi, yaitu pengumpulan data melalui pengamatan secara umum sebagai dasar untuk mengindentifikasi permasalahan yang akan dibahas.

3. Wawancara, yaitu mengumpulkan data dengan mengadakan tanya jawab secara lisan dengan pihak tenaga kerja pada waktu yang telah ditentukan.

4. Dokumentasi, yaitu teknik pengumpulan data melalui pencatatan dan pengumpulan data instansi yang berkaitan dengan permasalahan yang akan dibahas.

5. Kuisioner, yaitu pengumpulan data dengan cara membagikan daftar pertanyaan secara tertulis kepada tenaga kerja untuk memperoleh data primer yang diperlukan dalam penyusunan tesis ini.

\subsection{Teknik Analisis Data}

Dalam penelitian ini teknik pengolahan data yang akan dilakukan menggunakan metode kuantitatif yakni analisis bertujuan untuk membuat diskripsi, gambaran atau lukisan secara sistematis, faktual dan akurat mengenai fakta-fakta, sifat-sifat serta hubungan antar fenomena yang diselidiki secara terperinci untuk menghasilkan rekomendasi untuk keperluan di masa yang akan datang. Analisis data penelitian menggunakan analisis regresi berganda dengan perangkat lunak spss. Berdasarkan hal tersebut, alat uji yang digunakan adalah

\subsubsection{Uji Instrumen \\ 1. Validitas}


Data yang terkumpul akan berguna jika instrumen penelitian yang digunakan mempunyai nilai validitas dan reliabilitas lebih besar dari rtabel yang merupakan syarat untuk mendapatkan hasil penelitian yang valid dan reliable. Adapun penentuan atau pengambilan keputusan untuk valid instrumen pertanyaan dengan melihat nili corrected item total correllation (rhitung) dan untuk mengetahui validitas instrument pertanyaan harus dibandingkan dengan rtabel pada $\alpha$ 0,05 dengan derajat bebas $\mathrm{df}=\mathrm{jumlah}$ kasus (instrument pertanyaan), menurut Sulistyo (2010: 40), adalah Jika rhitung positif dan rhitung > rtabel maka instrument tersebut valid. Jika rtabel negative dan rhitung < rtabel maka instrument tidak valid.

\section{Reliabilitas}

Pengambilan keputusan untuk reliability instrumen pertanyaan adalah sebagai berikut jika ralpha positif dan ralpha > rtabel maka instrument tersebut reliable dan jika raplha negative dan rhitung < rtabel maka instrument tersebut tidak reliabel. Selain itu uji reliabilitas dapat dilakukan dengan menggunakan bantuan program SPSS, yang akan memberikan fasilitas untuk mengukur reliabilitas dengan uji statistik Cronbach Alpha $(\alpha)$. Suatu konstruk atau variabel dikatakan reliabel jika memberikan nilai Cronbanch Alpha > 0,60 (Ghozali,2009).

\subsubsection{Uji Asumsi Klasik}

\section{Uji Multikolinearitas}

Multikolinearitas, parameter yang mudah ditenggarai dari adanya Multikolinearitas, adalah deteksi terhadap gangguan multikolinearitas dapat dilihat dari nilai VIF (variance inflation factor) dan nilai tolerance (Pratsito, 2004, 156-161). Tolerance mengukur variabilitas variable bebas yang terpilih yang tidak dapat dijelaskan oleh variable bebas lainnya. Jadi ilai tolerance yang rendah sama dengan nilai VIF tinggi (karena VIF $=1 /$ tolerance) dan menunjukkan adanya koloniritas yang tinggi dan multikolineritas dapat diketahui dengan memeriksa nilai VIF (variance inflation factor) yang merupakan unsur diagonal invers matrik korelasi sederhana antara perubah bebas. Apabila beberapa nilai VIF lebih dari $10 \mathrm{mk}$ multikolienearitas adalah sebuah masalah (Solimun, 2004, 35).

2. Uji Heteroskedastisitas

Pemeriksaan terhadap gejala heteroskedastisitas menurut Pratisto (2004, 155) adalah dengan melihat pola diagram pencar. Nilai dari diagram pencar yag residu dapat dilihat dari selisih antara nilai $\mathrm{Y}$ prediksi dengan $\mathrm{Y}$ observasi. Jika diagram pencar yang membentuk pola-pola tertentu yang teratur maka regresi mengalami gangguan heteroskedastisitas dan jika diagram pencar tidak membentuk pola atau acak maka regresi tidak mengalami gangguan heteroskedastisitas.

3. Uji Normalitas (kenormalan)

Menurut Solimun (2004, 33) NID (normal independent distributed), yaitu berdistribusi normal atau saling bebas. Asumsi ini berarti bahwa kesalahan mengikuti sebaran normal dengan nilai tengah nol (0) dan ragam konstan ( $\mathrm{J}$ ). Asumsi ini sangat diperlukan pada pengujian hipotesisi, baik menggunakan uji t pada uji koefisien regresi secara parsial maupun uji $F$ pada uji koefiesien serempak melalui ANOVA regresi. Uji normaitas dilakukan untuk mengetahui apakah variable terikat dan variabel bebas dalam sebuah model regresi mempunyai distribusi normal atau tidak. Pemeriksanaan asumsi normalitas menurut Solimun $(2004,46)$ dapat dilakukan dengan cara membuat plot antara skor normal dengan data observasi dan melihat penyebaran data (titik) pada sumbu diagonal dari grafik. Bilamana hasil plot menujukkan pola garis lurus mendekati $45^{\circ}$ berarti asumsi normalitas terpenuhi.

\subsubsection{Uji Hipotesis}

\section{Analisis Regresi Berganda}

Analisis data dilakukan berdasarkan data primer yang diperoleh langsung dari penyebaran kuisioner kepada tenaga kerja yang selanjutnya akan dianalisis dengan paket program SPSS (statistic produk service solution) for windows melalui bantuan program komputer. Untuk menguji hipotesa dalam penelitian ini menggunakan analisis regresi linier berganda. Adapun rumus dari regresi linier berganda adalah sebagai berkut: 


$$
\mathrm{Y}=\mathbf{a}+\boldsymbol{\beta} 1 . \mathrm{X} 1+\boldsymbol{\beta} 2 . \mathrm{X} 2+\boldsymbol{\beta 3} . \mathrm{X} 3+\varepsilon
$$

Dimana :

$\begin{array}{ll}\mathrm{Y}= & \text { Kualitas tenaga kerja } \\ \mathrm{X} 1= & \text { Kompetensi } \\ \mathrm{X} 2= & \text { Sarana prasarana } \\ \mathrm{X} 3= & \text { Perencanaan dan program } \\ \text { pelatihan } & \\ \mathrm{B}= & \text { Koefisien Regresi } \\ \mathrm{a}=\quad & \text { Konstanta (bilangan yang nilainya } \\ \text { tetap) } & \\ \varepsilon= & \text { Faktor gangguan }\end{array}$

\section{Uji F (simultan)}

Dalam pengujian hipotesis secara simultan atau Uji $F$ digunakan untuk mengetahui apakah semua variabel independent (Xi) secara bersama-sama/simultan dapat terpengaruh terhadap variable dependen (Y). Tingkat kepercayaan yang digunakan adalah $95 \%$ atau taraf nyata ó sebesar 5\%, sedangkan yang menjadi derajat kebebasan $($ degree of freedom $)(\mathrm{df})=(\mathrm{k}-1)(\mathrm{n}-\mathrm{k})$ dimana $\mathrm{k}$ adalah jumlah variabel yang diteliti (variabel bebas + terikat) dan $\mathrm{n}$ adalah jumlah sampel atau responden (Priyatno, 2009:55) dan untuk menentukan $H_{A}$ diterima atau $\mathrm{H}_{\mathrm{A}}$ ditolak maka digunakan perbandingan Fhitung dengan Ftabel, yaitu Jika Fhitung < Ftabel berarti $\mathrm{H}_{\mathrm{A}}$ ditolak dan Jika Fhitung $>$ Ftabel berarti $\mathrm{H}_{\mathrm{A}}$ diterima.

\section{Uji Parsial}

Dalam pengujian hipotesis secara parsial atau Uji $t$ digunakan untuk menguji pengaruh masing-masing variabel independent (Xi) terhadap variabel dependen (Y) secara parsial. Tingkat kepercayaan yang digunakan adalah 95\% atau taraf nyata ó sebesara 5\% dengan derajat kebebasan $($ degree offreedom $)(\mathrm{df})=$ (n-k). $\mathrm{n}$ adalah jumlah sampel atau responden dan $\mathrm{k}$ adalah jumlah variabel yang diteliti (variabel bebas + terikat) (Priyatno, 2009:56) dan untuk menentukan $\mathrm{H}_{\mathrm{A}}$ diterima atau $\mathrm{H}_{\mathrm{A}}$ ditolak maka digunakan perbandingan thitung dengan ttabel, yaitu Jika thitung < ttabel berarti $\mathrm{H}_{\mathrm{A}}$ ditolak dan Jika thitung $>$ ttabel berarti $\mathrm{H}_{\mathrm{A}}$ diterima.

\section{Uji Variabel Dominan}

Untuk mengkaji variabel yang dominan digunakan indikator Standardized Koefisien Beta dari variabel-variabel dari model regresi. Standardized Koefisien Beta diperoleh dari hasil perkalian antara koefisien parsial korelasi ( $\left.\mathrm{SDx}_{1} / \mathrm{Sdy}\right)$ dan koefisien variabelnya (bi) dengan nilai beta mempunyai nilai kisaran mendekati 1 , (Pratisto (2004:160) selan itu dapat juga dilihat dengan melihat keeratan hubungan variabel dapat diambil dari thitung dengan standar ttabel.

\section{ANALISIS HASIL PENELITIAN DAN PEMBAHASAN}

\subsection{Analisis Hasil Penelitian}

\subsubsection{Pengujian Instrumen Penelitian}

\section{Uji Validitas}

Adapun hasil uji validitas dalam penelitian ini adalah sebagai berikut:

Tabel 5.9

Hasil Uji Validitas Variabel Kompetensi (X1)

\begin{tabular}{|c|c|c|}
\hline Variable & $\begin{array}{c}\text { rhitung } \\
\text { (lihat } \\
\text { lampiran 3) }\end{array}$ & $\begin{array}{c}\text { rtabel } \\
\text { (lihat } \\
\text { lampiran 6) }\end{array}$ \\
\hline $\mathrm{X} 1.1$ & $0,455(* *)$ & 0,263 \\
$\mathrm{X} 1.2$ & $0,467(* *)$ & 0,263 \\
$\mathrm{X} 1.3$ & $0,432(* *)$ & 0,263 \\
$\mathrm{X} 1.4$ & $0,429(* *)$ & 0,263 \\
$\mathrm{X} 1.5$ & $0,501(* *)$ & 0,263 \\
$\mathrm{X} 1.6$ & $0,511(* *)$ & 0,263 \\
\hline
\end{tabular}

Sumber : Data spss diolah

Berdasarkan tabel tersebut, hasil uji validitas terhadap instrumen pertanyaan variabel kompetensi (X1) di Dinas Tenaga Kerja Dan Transmigrasi Kabupaten Balangan Kalimantan Selatan yang diajukan terlihat dari 56 responden, menurut Sulistyo (2010: 40) terdapat nilai Table r (Pearson Product Moment) uji 1 sisi dan 2 sisi taraf signifikan 0,05 nilai rhitung sebesar 0,263.

Berdasarkan hal itu bila dibandingkan antara rhitung dengan rtabel tersebut, maka dapat disimpulkan bahwa semua instrumen pertanyaan tersebut valid, ini terbukti nilai rhitung positip dan rhitung > rtabel, maka semua instrumen dari pertanyaan variabel kompetensi (X1) valid.

Tabel 5.10

Hasil Uji Validitas Sarana Prasarana (X2) 


\begin{tabular}{|c|c|c|}
\hline Variable & $\begin{array}{c}\text { rhitung } \\
\text { (lihat } \\
\text { lampiran 3) }\end{array}$ & $\begin{array}{c}\text { rtabel } \\
\text { (lihat } \\
\text { lampiran 6) }\end{array}$ \\
\hline $\mathrm{X} 2.1$ & $0,492(* *)$ & 0,263 \\
$\mathrm{X} 2.2$ & $0,536\left(^{* *}\right)$ & 0,263 \\
\hline
\end{tabular}

Sumber : Data Spss diolah

Berdasarkan tabel tersebut, hasil uji validitas terhadap instrumen pertanyaan variabel sarana prasarana (X2) di Dinas Tenaga Kerja Dan Transmigrasi Kabupaten Balangan Kalimantan Selatan yang diajukan terlihat dari 56 responden, menurut Sulistyo (2010: 40) terdapat nilai Table r (Pearson Product Moment) uji 1 sisi dan 2 sisi taraf signifikan 0,05 nilai rhitung sebesar 0,263.

Berdasarkan hal itu bila dibandingkan antara rhitung dengan rtabel tersebut, maka dapat disimpulkan bahwa semua instrumen pertanyaan tersebut valid, ini terbukti nilai rhitung positip dan rhitung > rtabel, maka semua instrumen dari pertanyaan sarana prasarana (X2) tersebut valid.

\section{Tabel 5.11}

Hasil Uji Validitas

Perencanaan Program Pelatihan (X3)

\begin{tabular}{|c|c|c|}
\hline Variable & $\begin{array}{c}\text { rhitung } \\
\text { (lihat } \\
\text { lampiran 3) }\end{array}$ & $\begin{array}{c}\text { rtabel } \\
\text { (lihat } \\
\text { lampiran 6) }\end{array}$ \\
\hline X3.1 & $0,515(* *)$ & 0,263 \\
X3.2 & $0,481(* *)$ & 0,263 \\
X3.3 & $0,758(* *)$ & 0,263 \\
X3.4 & $0,765(* *)$ & 0,263 \\
\hline
\end{tabular}

Sumber : Data spss diolah

Hasil uji validitas terhadap instrumen pertanyaan variabel perencanaan program pelatihan (X3) di Dinas Tenaga Kerja Dan Transmigrasi Kabupaten Balangan Kalimantan Selatan yang diajukan terlihat dari 56 responden, menurut Sulistyo (2010: 40) terdapat nilai Table r (Pearson Product Moment) uji 1 sisi dan 2 sisi taraf signifikan 0,05 nilai rhitung sebesar 0,263.

Berdasarkan hal itu bila dibandingkan antara rhitung dengan rtabel tersebut, maka dapat disimpulkan bahwa semua instrumen pertanyaan tersebut valid, ini terbukti nilai rhitung positip dan rhitung > rtabel, maka semua instrumen dari pertanyaan variabel perencanaan program pelatihan (X3) tersebut valid.

\section{Table 5.12}

Hasil Uji Validitas
\begin{tabular}{|c|c|c|} 
Variabel Kualitas Tenaga Kerja (Y) \\
\hline Variable & $\begin{array}{c}\text { rhitung } \\
\text { (lihat } \\
\text { lampiran 3) }\end{array}$ & $\begin{array}{c}\text { Rtabel } \\
\text { (lihat } \\
\text { lampiran 6) }\end{array}$ \\
\hline Y1.1 & $0,453(* *)$ & 0,263 \\
Y1.2 & $0,459(* *)$ & 0,263 \\
Y1.3 & $0,496(* *)$ & 0,263 \\
Y1.4 & $0,489(* *)$ & 0,263 \\
\hline
\end{tabular}

Sumber : Data spss diolah

Berdasarkan tabel tersebut, hasil uji validitas terhadap instrumen pertanyaan variabel kualitas tenaga kerja (Y) di Dinas Tenaga Kerja Dan Transmigrasi Kabupaten Balangan Kalimantan Selatan yang diajukan terlihat dari 56 responden, menurut Sulistyo (2010: 40) terdapat nilai Table r (Pearson Product Moment) uji 1 sisi dan 2 sisi taraf signifikan 0,05 nilai rhitung sebesar 0,263.

Berdasarkan hal itu bila dibandingkan antara rhitung dengan rtabel tersebut, maka dapat disimpulkan bahwa semua instrumen pertanyaan tersebut valid, ini terbukti nilai rhitung positip dan rhitung > rtabel, maka semua instrumen dari pertanyaan variabel kualitas tenaga kerja (Y) pada Dinas Tenaga Kerja Dan Transmigrasi Kabupaten Balangan Kalimantan Selatan tersebut valid.

\section{Uji Reliabilitas}

Suatu konstruk atau variabel dikatakan reliabel jika memberikan nilai Cronbach $A_{\text {lpha }}>0,60$. (Ghozali, 2006, 41-42). Berikut rekapitulasi dari hasil uji reliabilitas instrument, sebagai berikut;

Tabel 5.13 Hasil Uji Reliabilitas

\begin{tabular}{|l|c|c|}
\hline \multicolumn{1}{|c|}{ Variable } & $\begin{array}{c}\text { Cronbach } \\
\mathrm{A}_{\text {lpha }} \\
\text { (lihat } \\
\text { lampiran } \\
4 \text { ) }\end{array}$ & $\begin{array}{c}\text { Nilai } \\
\text { Baku }\end{array}$ \\
\hline Kompetensi (X1) & 0,675 & 0,60 \\
Sarana prasarana (X2) & 0,710 & 0,60 \\
Perencanaan Program & 0,740 & 0,60 \\
Pelatihan (X3) & 0,817 & 0,60 \\
Kualitas Tenaga Kerja (Y) & & \\
\hline
\end{tabular}

Sumber: Data spss diolah

Melihat hasil uji tersebut nilai Cronbach

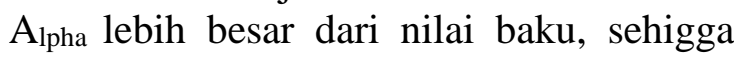
dengan demikian dapat dikatakan data hasil 
uji reliabilitas masing-masing variabel datanya reliabel.

\subsubsection{Uji Asumsi Klasik}

\section{Uji Multikolinieritas}

Berikut hasil uji multikolinieritas dalam penelitian ini, yaitu:

\section{Tabel 5.14}

Hasil Uji Multikolinieritas

\begin{tabular}{|l|c|c|}
\hline \multirow{2}{*}{ Variabel } & \multicolumn{2}{|c|}{ Collinierarity Statistic's } \\
\cline { 2 - 3 } & Tolerance & VIF \\
\hline $\begin{array}{l}\text { Kompentensi } \\
\text { (X1) }\end{array}$ & 0,998 & 1,344 \\
\hline $\begin{array}{l}\text { Sarana } \\
\text { Prasarana } \\
\text { (X2) }\end{array}$ & 0,992 & 1,212 \\
\hline $\begin{array}{l}\text { Perencanaan } \\
\text { Program } \\
\text { Pelatihan (X3) }\end{array}$ & 0,898 & 1,178 \\
\hline
\end{tabular}

Sumber: Lampiran 5

Melihat data tersebut dapat disimpulkan hasil uji multikolinieritas tidak ada gejala multikolinieritas antar variabel bebas dalam model regresi karena nilai tolerance mendekati 1 dan nilai variance inflation factor (VIF) menunjukkan tidak ada satu pun variabel bebas yang memiliki nilai VIF lebih dari 10.

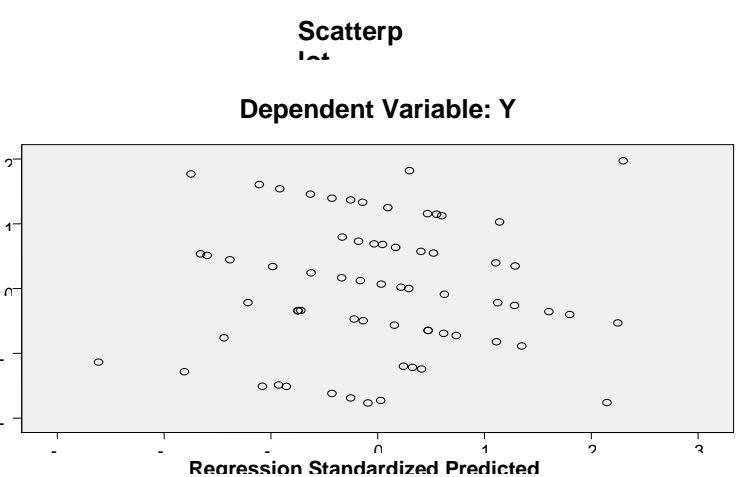

\section{Uji Heteroskedastisitas}

Berikut hasil uji heteroskedastisitas dapat digambarkan sebagai berikut:

Gambar 5.2 : Scatterplot

$$
\text { Sumber : lampiran } 5
$$

Grafik scatterplots di atas ini terlihat titiktitik menyebar secara acak serta tersebar baik di atas maupun di bawah angka 0 pada sumbu Y. Hal ini dapat disimpulkan bahwa tidak terjadi heteroskedastisitas pada model regresi, sehingga model regresi layak dipakai untuk memprediksi variabel terikat berdasarkan pengaruh variabel bebas pada
Dinas Tenaga Kerja Dan Transmigrasi Kabupaten Balangan Kalimantan Selatan.

\section{Uji Normalitas}

Adapun hasil dari uji normalitas dalam penelitian ini, yaitu:

\section{Gambar 5.3 Diagram Normal P-P Plot Sumber: lampiran 5}

Hasil uji normalitas menunjukkan bahwa grafik terlihat titik-titik menyebar disekitar garis diagonal, serta penyebarannya mengikuti arah garis diagonal, ini menunjukkan bahwa model regresi layak dipakai untuk memprediksi variabel dependen berdasarkan masukan dari variabel independen pada Dinas Tenaga Kerja Dan Transmigrasi Kabupaten Balangan Kalimantan Selatan, karena memenuhi uji asumsi normalitas.

\subsubsection{Analisis Regresi Berganda}

Berikut hasil uji regresi berganda melalui program spss, berikut ini disampaikan rekapitulasi hasil regresi berganda tersebut, adalah :

\section{Tabel 5.15 Analisis Regresi Berganda Coefficients(a)}

\begin{tabular}{|c|c|c|c|c|c|c|c|}
\hline & \multicolumn{2}{|c|}{$\begin{array}{c}\text { Unstandar } \\
\text { dized } \\
\text { Coefficie } \\
\text { nts }\end{array}$} & $\begin{array}{c}\text { Standar } \\
\text { dized } \\
\text { Coeffic } \\
\text { ients }\end{array}$ & \multirow[b]{2}{*}{$\mathrm{t}$} & \multirow[b]{2}{*}{$\begin{array}{l}\mathrm{Si} \\
\mathrm{g} .\end{array}$} & \multicolumn{2}{|c|}{$\begin{array}{l}\text { Collinearit } \\
\text { y Statistics }\end{array}$} \\
\hline & B & $\begin{array}{l}\text { Std } \\
\text { Err } \\
\text { or }\end{array}$ & Beta & & & $\begin{array}{l}\text { Toler } \\
\text { ance }\end{array}$ & $\begin{array}{l}\text { VI } \\
\mathrm{F}\end{array}$ \\
\hline (Cons & 22, & 4,1 & & 5,3 & ,0 & & \\
\hline $\operatorname{tant})$ & 257 & 73 & & 33 & 00 & & \\
\hline X1 &, 77 &, 11 & 773 & 6,9 &, 0 & 008 & 1,3 \\
\hline & 5 & 2 &,$/ 13$ & 19 & 00 & ,998 & 44 \\
\hline $\mathrm{X} 2$ & ,69 &, 11 & 690 & 6,3 &, 0 & 992 & 1,2 \\
\hline & 8 & 0 & 690 & 45 & 01 & ,992 & 12 \\
\hline X3 & ,59 &, 12 & 506 & 4,6 & ,0 & 800 & 1,1 \\
\hline & 9 & 9 & & 43 & 02 & ,898 & 78 \\
\hline
\end{tabular}

a Dependent Variable: Y

Sumber: Output Spss Diolah (lihat lampiran 5)

Hasil perhitungan dari pengaruh antar variabel kompetensi (X1), saran prasarana (X2) dan perencanaan program pelatihan terhadap kualitas tenaga kerja (Y), maka dapat disusun persamaan struktural untuk model regresi sebagai berikut:

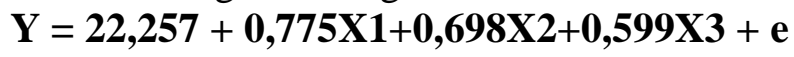

\subsubsection{Uji Hipotesis}

\section{Uji Hipotesis Pertama}

Kompetensi berpengaruh signifikan terhadap kualitas tenaga kerja pada Dinas 
Tenaga Kerja Dan Transmigrasi Kabupaten Balangan Kalimantan Selatan.

Untuk mengetahui akan pengujian hipotesis pertama terlebih dahulu harus diketahui akan ttabel dengan cara mendapatkan ttabel digunakan tabel distribusi t untuk tingkat signifikasi 5\% dengan Degrees of Freedom $(\mathrm{df})=\mathrm{n}-\mathrm{k}$ maka di dapat df adalah (56-4)= 52 dengan demikian ttabel adalah sebesar 1,675. Berdasarkan hal tersebut diketahui hasil uji regresi dan penetapan data pada tabel baku ttabel, maka dapat dilihat dari perbandingan nilai thitung lebih besar dari $\mathrm{t}_{\text {tabel }}$ yaitu : $\left(\mathrm{t}_{\text {hitung }}=6,919>\mathrm{t}_{\text {tabel }}=1,675\right)$ atau signifikansi $p<0,05$ yaitu $0,000<$ 0,05 ,

nanandant Variahla. $V$

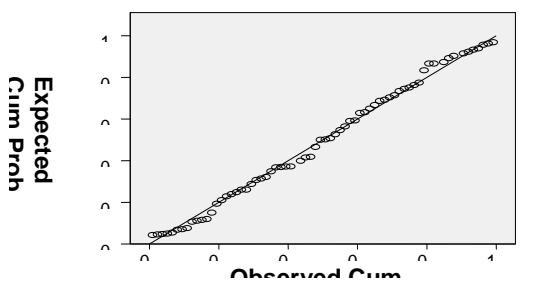

berdasarkan hasil tersebut maka hipotesis pertama yang menyebutkan secara parsial antara variabel kompetensi berpengaruh signifikan terhadap kualitas tenaga kerja pada Dinas Tenaga Kerja Dan Transmigrasi Kabupaten Balangan Kalimantan Selatan, diterima. Besarnya pengaruh variabel kompentensi (X1) terhadap kualitas tenaga kerja (Y) pada Dinas Tenaga Kerja Dan Transmigrasi Kabupaten Balangan Kalimantan Selatan dapat diketahui dari Standardized Coefficients Beta 0,773 yang berarti kompetensi ini memberikan konstribusi dalam mempengaruhi kualitas tenaga kerja terhadap sebesar $77,3 \%$.

\section{Uji Hipotesis Kedua}

Sarana prasarana berpengaruh signifikan terhadap kualitas tenaga kerja pada Dinas Tenaga Kerja Dan Transmigrasi Kabupaten Balangan Kalimantan Selatan

Kemudian untuk pengujian hipotesis ke dua dilakukan dengan juga dengan melihat hasil uji regresi dan penetapan data pada tabel baku ttabel, maka dapat dilihat dari perbandingan nilai $\mathrm{t}_{\text {hitung }}$ lebih besar dari $t_{\text {tabel }}$ yaitu : $\left(t_{\text {hitung }}=6,345>t_{\text {tabel }}=1,675\right)$ atau signifikansi $p<0,05$ yaitu $0,001<$ 0,05 , berdasarkan hasil tersebut maka hipotesis kedua yang menyebutkan secara parsial antara variabel sarana prasarana berpengaruh signifikan terhadap kualitas tenaga kerja pada Dinas Tenaga Kerja Dan Transmigrasi Kabupaten Balangan Kalimantan Selatan, diterima. Besarnya pengaruh variabel sarana prasarana (X2) terhadap kualitas tenaga kerja (Y) pada Dinas Tenaga Kerja Dan Transmigrasi Kabupaten Balangan Kalimantan Selatan dapat diketahui dari Standardized Coefficients Beta 0,690 yang berarti sarana prasarana ini memberikan konstribusi dalam mempengaruhi kualitas tenaga kerja terhadap sebesar $69 \%$

\section{Uji Hipotesis Ketiga}

Perencanaan program pelatihan berpengaruh signifikan terhadap kualitas tenaga kerja pada Dinas Tenaga Kerja Dan Transmigrasi Kabupaten Balangan Kalimantan Selatan

Hasil uji regresi dan penetapan data pada tabel baku ttabel, maka dapat dilihat dari perbandingan nilai $t_{\text {hitung }}$ lebih besar dari $\mathrm{t}_{\text {tabel }}$ yaitu : $\left(\mathrm{t}_{\text {hitung }}=4,643>\mathrm{t}_{\text {tabel }}=1,675\right)$ atau signifikansi $p<0,05$ yaitu $0,002<$ 0,05 , berdasarkan hasil tersebut maka hipotesis ketiga yang menyebutkan secara parsial antara variabel perencanaan program pelatihan berpengaruh signifikan terhadap kualitas tenaga kerja pada Dinas Tenaga Kerja Dan Transmigrasi Kabupaten Balangan Kalimantan Selatan, diterima. Besarnya pengaruh variabel perencanaan program pelatihan (X3) terhadap kualitas tenaga kerja (Y) pada Dinas Tenaga Kerja Dan Transmigrasi Kabupaten Balangan Kalimantan Selatan dapat diketahui dari Standardized Coefficients Beta 0,596 yang berarti perencanaan program pelatihan ini memberikan konstribusi dalam mempengaruhi kualitas tenaga kerja sebesar 59,6\%.

\section{Uji Hipotesis Keempat}

Kompetensi, sarana prasarana dan perencanaan program pelatihan berpengaruh signifikan secara simultan terhadap kualitas tenaga kerja pada Dinas Tenaga Kerja Dan Transmigrasi Kabupaten Balangan Kalimantan Selatan. Selanjutnya untuk menguji pengaruh secara simultan data yang digunakan adalah tabel: 
Tabel 5.16 ANOVA(b)

\begin{tabular}{|l|r|r|r|c|c|}
\hline & $\begin{array}{r}\text { Sum of } \\
\text { Squares }\end{array}$ & Df & $\begin{array}{c}\text { Mean } \\
\text { Square }\end{array}$ & F & Sig. \\
\hline Regression & 147,891 & 3 & 49,297 & 7,296 &, $000(a)$ \\
Residual & 35,808 & 53 & 6,756 & & \\
Total & 183,699 & 56 & & & \\
\hline
\end{tabular}

Hasil regresi memperlihatkan bahwa $F_{\text {hitung }}$ adalah 7,296 sedangkan untuk mengetahui akan nilai $\mathrm{F}_{\text {table }}$ dengan cara menentukan tingkat signifikan $5 \%$ kemudian menentukan derajat bebas bagi pembilang (numerator) dengan dasar (k-1) sehingga didapat $(4-1)=3$, sedangkan derajat kebebasan bagi pembagi (denumerator) adalah (n-k) sehingga didapat $(56-4)=52$. Dengan demikian didapat $F_{\text {tabel }}$ dengan numerator $=3$ dan denumurator 52 sebesar 2,783. Berdasarkan data tersebut, maka diketahui bahwa pengujian hipotesis keempat menunjukkan bahwa variabel kompentensi (X1), sarana prasarana (X2) dan perencanaan program pelatihan (X3) secara simultan berpengaruh signifikan terhadap kualitas tenaga kerja (Y) pada Dinas Tenaga Kerja Dan Transmigrasi Kabupaten Balangan Kalimantan Selatan, hal ini berdasarkan dari nilai $F_{\text {hitung }}$ lebih besar dari $F_{\text {tabel }}$ yakni : $\left(F_{\text {hitung }}=7,296>\right.$ $\left.\mathrm{F}_{\text {tabel }}=2,783\right)$ atau signifikansi $p<0,05$ yaitu $0,000<0,05$. Tingkat kepercayaan yang diambil dalam penelitian ini sebesar 95\% dengan tingkat kesalahan $(\alpha)$ sebesar $5 \%$. Dengan demikian hipotesis keempat (H4) yang menyatakan bahwa secara simultan variabel kompentensi (X1), sarana prasarana (X2) dan perencanaan program pelatihan (X3) secara simultan berpengaruh signifikan terhadap kualitas tenaga kerja (Y) pada Dinas Tenaga Kerja Dan Transmigrasi Kabupaten Balangan Kalimantan Selatan, maka hipotesis keempat (H4), diterima. Kemudian untuk melihat seberapa besar pengaruh dari variabel kompentensi (X1), sarana prasarana (X2) dan perencanaan program pelatihan (X3) secara simultan berpengaruh signifikan terhadap kualitas tenaga kerja (Y) pada Dinas Tenaga Kerja Dan Transmigrasi Kabupaten Balangan Kalimantan Selatan, dapat dilihat dengan uji determinan, untuk itu data yang diperlukan adalah :
Tabel 5.17 Model Summary(b)

\begin{tabular}{|l|r|r|r|r|}
\hline \multirow{2}{*}{ odel } & & & & \\
& $\mathrm{R}$ & R Square & $\begin{array}{c}\text { Adjusted } \\
\text { R Square }\end{array}$ & $\begin{array}{c}\text { Durbin- } \\
\text { Watson }\end{array}$ \\
\hline 1 &, $844(\mathrm{a})$ &, 805 &, 742 & 1,893 \\
\hline
\end{tabular}

a Predictors: (Constant), X3X2,X1

b Dependent Variable: Y

Sumber : data primer diola (lihat lampiran 5)

Uji determinan adalah untuk regresi dengan lebih dari dua variabel bebas digunakan $R$ Square sebagai keofesien diterminan dari data tersebut terlihat $R$ Square sebesar 0,805 disini berarti $88,7 \%$ variasi kualitas tenaga kerja (Y) pada Dinas Tenaga Kerja Dan Transmigrasi Kabupaten Balangan Kalimantan Selatan bisa dijelaskan oleh variabel seperti kompentensi (X1), sarana prasarana (X2) dan perencanaan program pelatihan (X3), sedangkan sisanya dari $(100 \%-80,5 \%)=19,5 \%$ dijelaskan oleh variabel lain yang tidak dianalisis pada penelitian ini seperti faktor individu, faktor disiplin maupun faktor pihak ketiga (pengusaha) dan lain-lain.

\subsection{Pembahasan}

1. Kompetensi berpengaruh signifikan terhadap kualitas tenaga kerja pada Dinas Tenaga Kerja Dan Transmigrasi Kabupaten Balangan Kalimantan Selatan

Hasil penelitian pada hipotesis pertama secara parsial diketahui bahwa variabel kompetensi berpengaruh signifikan terhadap kualitas tenaga kerja pada Dinas Tenaga Kerja Dan Transmigrasi Kabupaten Balangan Kalimantan Selatan. Besarnya pengaruh variabel kompentensi terhadap kualitas tenaga kerja sebesar 77,3\%. Hal ini sejalan juga dengan teori yang dikemukakan oleh Menurut Hutabarat (2007 : 297), kompetensi adalah suatu ilmu pengetahuan atau mengetahui bagaimana untuk melakukan kerja yang efektif.

Berdasarkan hal tersebut, maka pihak Dinas Tenaga Kerja Dan Transmigrasi Kabupaten Balangan Kalimantan Selatan perlu lebih meningkatkan kembali kemampuan para petugas / instruktur guna meningkatkan kualitas tenaga kerja agar dapat bersaing didunia kerja, adapun upaya yang dapat dilakukan untuk meningkatkan para petugas 
dan instruktur tersebut dapat dilakukan dengan cara memberikan diklat melalui pengembangan intelektual, yaitu sekolah atau kuliah. Pengembangan kemampuan, yaitu diskusi kasus dan pengembangan sikap dan dinamika kejiwaan, yaitu permainan (game), sensitivity training dan lain-lain.

2. Sarana prasarana berpengaruh signifikan terhadap kualitas tenaga kerja pada Dinas Tenaga Kerja Dan Transmigrasi Kabupaten Balangan Kalimantan Selatan

Hasil penelitian pada hipotesis kedua secara parsial diketahui bahwa variable sarana prasarana berpengaruh signifikan terhadap kualitas tenaga kerja pada Dinas Tenaga Kerja Dan Transmigrasi Kabupaten Balangan Kalimantan Selatan. Besarnya pengaruh variabel sarana prasarana terhadap kualitas tenaga kerja sebesar $69 \%$. Hal ini sejalan juga dengan teori yang dikemukakan oleh Berta (2011:95) menjeleaskan tentang sarana adalah segala sesuatu yang dapat dipakai sebagai alat dalam mencapai maksud atau tujuan, sedangkan prasarana adalah segala sesuatu yang merupakan penunjang utama terselenggaranya suatu proses atau aktivitas. Berdasarkan hal tersebut, maka pihak Dinas Tenaga Kerja Dan Transmigrasi Kabupaten Balangan Kalimantan Selatan perlu lebih memperhatikan kembali akan sarana prasarana bagi pengembangan tenaga kerja yaitu melalui usaha meningkatkan peralatan kerja yaitu semua jenis benda yang berfungsi sebagai alat pembantu tidak langsung dalam pekerjaan atau produks, mempercepat proses, membangkit dan menambah kenyamanan dalam pekerjaan para tenaga kerja yang lagi latihan di BLK. Menambah perlengkapan kerja yaitu semua jenis benda yang berfungsi sebagai alat pembantu tidak langsung dalam proses pekerjaan, mempercepat proses, membangkit dan menambah kenyamanan dalam pekerjaan bagi instruktur dan menambah elengkapan bantu atau fasilitas yaitu semua jenis benda yang berfungsi membantu kelancaran gerak dalam pelatihan dan pendidikan bagi tenaga kerja.
3. Perencanaan program pelatihan berpengaruh signifikan terhadap kualitas tenaga kerja pada Dinas Tenaga Kerja Dan Transmigrasi Kabupaten Balangan Kalimantan Selatan

Hasil penelitian pada hipotesis ketiga secara parsial diketahui bahwa variable perencanaan program pelatihan berpengaruh signifikan terhadap kualitas tenaga kerja pada Dinas Tenaga Kerja Dan Transmigrasi Kabupaten Balangan Kalimantan Selatan. Besarnya pengaruh variabel perencanaan program pelatihan terhadap kualitas tenaga kerja sebesar $59,6 \%$. Hal ini sejalan juga dengan teori yang dikemukakan oleh Sutrisno (2011:88) menjelaskan perencanaan merupakan faktor penting dalam sebuah program diklat. Perencanaan yang baik akan dapat membantu lembaga penyelenggara dalam melaksanakan kegiatnnya dengan terpadu sehingga dapat mencapai hasil yang maksimal.

Berdasarkan hal tersebut, maka pihak Dinas Tenaga Kerja Dan Transmigrasi Kabupaten Balangan Kalimantan Selatan perlu lebih memperhatikan kembali dan mempunyai komitmen yang kuat terhadap perencanaan program pelatihan selain itu program dan kegiatan yang dituangkan harus sesuai Rencana Strategis Dinas Tenaga Kerja dan Transmigrasi yang mengacu pada Rencana Pembangunan Jangka Menengah Daerah (RPJMD) Kabupaten Balangan dalam rangka pencapaian visi dan misi. Adapun program dan kegiatan yang akan dilaksanakan terdiri dari usaha Program Peningkatan Kualitas dan Produktivitas Tenaga Kerja dengan tujuan program ini adalah untuk meningkatkan keterampilan, keahlian, kompetensi tenaga kerja dan meningkatkan produktivitas tenaga kerja. Program Peningkatan Kesempatan Kerja dengan tujuan program ini adalah untuk mendorong penciptaan kesempatan kerja dan penempatan tenaga kerja dalam rangka mengurangi penganggur dan setengah penganggur, baik di perdesaan maupun di perkotaan, serta memenuhi kebutuhan pasar kerja internasional.

Perencanaan program tersebut harus dapat dikejar sesuai terget dan komitmen yang 
tinggi untuk mencapainnya, sehingga perencanaan program peltihan dapat berjalan sesuai dengan yang diharapkan Dinas Tenaga Kerja Dan Transmigrasi Kabupaten Balangan Kalimantan Selatan.

4. Kompetensi, sarana prasarana dan perencanaan program pelatihan berpengaruh signifikan secara simultan terhadap kualitas tenaga kerja pada Dinas Tenaga Kerja Dan Transmigrasi Kabupaten Balangan Kalimantan Selatan

Hasil penelitian pada hipotesis ke empat secara simultan diketahui bahwa variable kompetensi, sarana prasarana dan perencanaan program pelatihan berpengaruh signifikan secara simultan terhadap kualitas tenaga kerja pada Dinas Tenaga Kerja Dan Transmigrasi Kabupaten Balangan Kalimantan Selatan

Besarnya pengaruh variabel perencanaan program pelatihan terhadap kualitas tenaga kerja sebesar 80,5\%. Berdasarkan hal tersebut, maka pihak Dinas Tenaga Kerja Dan Transmigrasi Kabupaten Balangan Kalimantan Selatan perlu lebih memperhatikan kembali dan berkomitmen yang kuat dalam mengembangkan variabel kompetensi, sarana prasarana dan perencanaan program pelatihan, dengan selalu mengevaluasi kompetesi para petugas atau instruktur, mengevaluasi sarana prasarana yang dimiliki sarana apa saja yang kurang sebisa mungkin diupayakan untuk melengkapinya agar tenaga kerja dalam mengikuti bimbingan dan pelatihan dalam belajar dengan baik selain itu terhadap perencanaan progra pelatihan hendaknya pihak Dinas Tenaga Kerja Dan Transmigrasi Kabupaten Balangan Kalimantan Selatan harus benarbenar serius dan fokus terhadap program kerja dan sebisa mungkin program kerja tersebut dapat dicapai dengan cara disiplin kerja yang tinggi dan semangat kerja yang tinggi pula agar para tenaga kerja dapat menimba ilmu dan keterampilan sesuai dengan lapangan kerja yang dibutuhkan dan mendapatkan kerja sesuai dengan minat dan bakatnya.

\section{PENUTUP}

\subsection{Kesimpulan}

1. Hipotesis pertama menyebutkan secara parsial antara variabel kompetensi berpengaruh signifikan terhadap kualitas tenaga kerja pada Dinas Tenaga Kerja Dan Transmigrasi Kabupaten Balangan Kalimantan Selatan. Besarnya pengaruh variabel kompentensi terhadap kualitas tenaga kerja sebesar $77,3 \%$.

2. Hipotesis kedua menyebutkan secara parsial antara variabel sarana prasarana berpengaruh signifikan terhadap kualitas tenaga kerja pada Dinas Tenaga Kerja Dan Transmigrasi Kabupaten Balangan Kalimantan Selatan. Besarnya pengaruh variabel sarana prasarana terhadap kualitas tenaga kerja sebesar $69 \%$.

3. Hipotesis ketiga yang menyebutkan secara parsial antara variabel perencanaan program pelatihan berpengaruh signifikan terhadap kualitas tenaga kerja pada Dinas Tenaga Kerja Dan Transmigrasi Kabupaten Balangan Kalimantan Selatan. Besarnya pengaruh variabel perencanaan program pelatihan terhadap kualitas tenaga kerja sebesar $59,6 \%$

4. Pengujian hipotesis keempat menunjukkan bahwa variabel kompentensi, sarana prasarana dan perencanaan program pelatihan secara simultan berpengaruh signifikan terhadap kualitas tenaga kerja. Besar pengaruh secara simultan adalah sebesar $80,5 \%$.

\subsection{Saran}

a. Dinas Tenaga Kerja Dan Transmigrasi Kabupaten Balangan Kalimantan Selatan perlu lebih meningkatkan kembali kemampuan para petugas / instruktur dengan cara memberikan diklat melalui pengembangan intelektual, yaitu sekolah atau kuliah. Pengembangan kemampuan, yaitu diskusi kasus dan pengembangan sikap dan dinamika kejiwaan, yaitu permainan (game), sensitivity training dan lain-lain.

b. Dinas Tenaga Kerja Dan Transmigrasi Kabupaten Balangan Kalimantan Selatan perlu lebih memperhatikan kembali akan sarana prasarana melalui usaha meningkatkan peralatan kerja 
yaitu semua jenis benda yang berfungsi sebagai alat pembantu tidak langsung dalam pekerjaan atau produks, mempercepat proses, membangkit dan menambah latihan di BLK. Menambah perlengkapan kerja yaitu alat pembantu tidak langsung dalam proses pekerjaan, mempercepat proses, membangkit dan menambah kenyamanan dalam pekerjaan bagi instruktur dan menambah elengkapan bantu atau fasilitas yaitu semua jenis benda yang berfungsi membantu kelancaran gerak dalam pelatihan dan pendidikan bagi tenaga kerja.

c. Dinas Tenaga Kerja Dan Transmigrasi Kabupaten Balangan Kalimantan Selatan perlu lebih memperhatikan kembali dan mempunyai komitmen yang kuat terhadap perencanaan program pelatihan selain itu program dan kegiatan yang dituangkan harus sesuai Rencana Strategis Dinas Tenaga Kerja dan Transmigrasi yang mengacu pada Rencana Pembangunan Jangka Menengah Daerah (RPJMD) Kabupaten Balangan dalam rangka pencapaian visi dan misi.

d. Dinas Tenaga Kerja Dan Transmigrasi Kabupaten Balangan Kalimantan Selatan perlu lebih memperhatikan kembali dan berkomitmen yang kuat dalam mengembangkan variabel kompetensi, sarana prasarana dan perencanaan program pelatihan, dengan selalu mengevaluasi kompetesi para petugas atau instruktur, mengevaluasi sarana prasarana yang dimiliki sarana apa saja yang kurang sebisa mungkin diupayakan untuk melengkapinya terhadap perencanaan program pelatihan hendaknya benar-benar serius dan fokus terhadap program kerja dan sebisa mungkin program kerja tersebut dapat dicapai dengan cara disiplin kerja yang tinggi dan semangat kerja yang tinggi pula agar para tenaga kerja dapat menimba ilmu dan keterampilan sesuai dengan lapangan kerja yang dibutuhkan.

DAFTAR PUSTAKA
Arikunto Suharsimi, 2006, Prosedur Penelitian Suatu Pendekatan dan Praktek, Rineka Cipta, Jakarta

Basri, Andrian, 2009, Manajemen Sumber Daya Manusia, Bumi Aksara, Jakarta

Berta, 2011, Manajemen, Rineka Cipta, Jakarta

Brotoharsojo, 2013, Manajemen Tenaga Kerja, Rineka Cipta, Jakarta

Dewi, 2012, Manajemen Pelayanan Publik, Books, Jakarta

Davis, 1999, Organization. 5th Edition. Terjemahan Djakarsih. Erlangga. Jakarta:

Darmawan, 2012, Manajemen Saran dan Prasarana Kerja, CV.Hasanu. Media, Surabaya

Douglas, 2009, Organazation Planning, Mell Media, Malaysia

Eka Putri, 2012, Pengaruh Kompetensi, Diklat dan Sarana prasarana

Terhadap Kualitas Pegawai Pada Dinas Kesehatan Kota Banjarmasin, FE.Unlam, Banjarmasin

Emmy Sopyan, 2012, Pengaruh Kompetensi, Saran prasarana, Program Pelatihan Terhadap Kualitas Pegawai Pada Kantor Dinas Pendapatan Kota Banjarmasin FE.Unlam, Banjarmasin

Erly Suandy, 2001, Perencanaan Bisnis, Bumi Aksara, Jakarta

Erwin, 2012, Ketenagakerjaan dan Keorganisasian, Rineka Cipta, Jakarta

Farland. Hakim, 2011, Manajemen Perencanaan Organisasi, Rineka Cipta, Jakarta

Handoko. T. Hani, 2001, Manajemen SDM dan Kepersonalian, BPFE, Yogyakarta , 2012, Manajemen SDM dan Kepersonalian, Edisi Revisi, BPFE, Yogyakarta

Hartanto,2012, Manajemen, Bumi Aksara, Jakarta

Husnan, 1991, Manajemen Sumber Daya Manusia, Ghalia Indonesia, Jakarta 
, 2000, Manajemen Sumber Daya Manusia, Edisi Revisi, Ghalia Indonesia, Jakarta

Ginting, 2000, Manajemen SDM, Rineka Cipta, Jakarta

Ghozali, 2009, Metode Peneitian dan Riset dengan Aplikasi SPSS, Rajawali Press, Jakarta

Gede, 2012, Manajemen Sumber Daya Manusia, Rineka Cipta, Jakarta

Komariah, 2009, Manajemen Keorganisasian, Rineka Cipta, Jakarta

Mulyasa, 2007, Manajemen Rekayasa dan Sarana Prasarana, Gramedia, Jakarta

Makmur, 2009, Pelayanan Publik Yang Profesional, Liberty,Jakarta

Murti,2012, Manajemen SDM, PT. Rajawali Press, Jakarta

Hutabarat, 2007, Manajemen Sumber Daya Manusia, Rineka Cipta, Jakarta

Matutina, 2001, Manajemen Ketenagakerjaan, Rineka Cipta, Jakarta

Moenir, 2002, Manajemen Pelayanan Publik, Bumi Aksara, Jakarta

Moerdino, 2012, Manajemen Sumber Daya Manusia, Edisi III, Liberty, Jakarta

Moejikat, 1999, Manajemen Kepegawaian, Balai Pustaka, Jakarta

Nitisemito. Alex, 2011, Manajemen Sumber Daya Manusia Dan Kepersonalian, Edisi Baru, Ghalia Indonesia, Jakarta

Pratisto, Arif, 2004, Cara Mudah Mengatasi Statistik dan Rancangan Percobaan dengan SPSS 12, PT Elex Media Komputindo Kelompok Gramedia, Jakarta

Prayitno, 2006, Manajemen Kepersonalian, Liberty, Jakarta

PP No. 101 Tahun 2000 dinyatakan Pendidikan dan Pelatihan Jabatan Pegawai Negeri Sipil, Jakarta
Priyatno, 2009, Metodologi Penelitian, Rineka Cipta, Jakarta

Rustiadi 2008, Perencanaan Organisasi, Rineka Cipta, Jakarta

Rivai Vincent, 2009, Manajemen Sumber Daya Manusia, Ghalia Indonesia, Jakarta

Setiawan, 2013, Pengaruh Kompetensi, Pelatihan Terhadap Kinerja Pegawai Pada Kantor BNN Kabupaten Balangan, FE Unlam, Banjarmasin

Sagala, 2009, Manajemen Sumber Daya Manusia, PT Pelita, Bandung

Riyanto, 2010, Manajemen, Rineka Cipta, Jakarta

Roesmingsih, 2009, Evaluasi dan Perencanaan Kerja, Median Putra Jaya Press, Jakarta

Satriawan, 2003, Manajemen dan Keorganisasian, Pustaka Karyawa, Jakarta

Soemarno, 2010, Manajemen Ketenagakerjaan, Buana Cipta, Surabaya

Setiawan, 2010, Fasilitas Keorganisasi, Bumi Aksara, Jakarta

Spencer ,2003, Strategis for persuasive communication and competence. Charles.E. Merril Publishing Company A. Bell dan Howel Company Columbus, Ohio.

Sugiono, 2009, Metode Penelitian Admisnitrasi, Alfabeta, Bandung

Solimun, 2004, Metodologi dan Komputer Statistik, PT. Rajawali Press, Jakarta

Sutrisno, 2011, Manajemen Perencanaan Bisnis, Media Pustaka, Jakarta

Susilo, 2003, Penghantar Ilmu Manajemen, Rineka Cipta, Jakarta

Tulus Putra, 2012, Manajemen Sumber Daya Manusia, Media Pustaka, Jakarta 
UU No. 13 Tahun 2003, Tenaga Kerja, Jakarta

Ukas, 1999, Manajemen Kepegawaian, Rineka Cipta, Jakarta

Warny. Purwatyningsih, 2010, Manajemen Sumber Daya Manusia (MSDM), Rineka Cipta, Jakarta

Wijono, 2010, Manajemen Sumber Daya Manusia, Balai Pustaka, Jakarta 